University of Louisville

ThinkIR: The University of Louisville's Institutional Repository

$8-2005$

\title{
Ridge augmentation comparing a cancellous block allograft to freeze dried bone particles and utilizing an acellular dermal matrix barrier membrane.
}

\author{
Brenton Lahey \\ University of Louisville
}

Follow this and additional works at: https://ir.library.louisville.edu/etd

\section{Recommended Citation}

Lahey, Brenton, "Ridge augmentation comparing a cancellous block allograft to freeze dried bone particles and utilizing an acellular dermal matrix barrier membrane." (2005). Electronic Theses and Dissertations. Paper 787.

https://doi.org/10.18297/etd/787

This Master's Thesis is brought to you for free and open access by ThinkIR: The University of Louisville's Institutional Repository. It has been accepted for inclusion in Electronic Theses and Dissertations by an authorized administrator of ThinkIR: The University of Louisville's Institutional Repository. This title appears here courtesy of the author, who has retained all other copyrights. For more information, please contact thinkir@louisville.edu. 


\title{
RIDGE AUGMENTATION COMPARING A CANCELLOUS BLOCK ALLOGRAFT TO FREEZE DRIED BONE PARTICLES AND UTILIZING AN ACELLULAR DERMAL MATRIX BARRIER MEMBRANE
}

\author{
By \\ Brenton Lahey \\ DMD, Temple University, 2002
}

\author{
A Thesis \\ Submitted to the Faculty of the \\ Graduate School of the University of Louisville \\ in Partial Fulfillment of the Requirements \\ for the Degree of
}

Master of Science

Program in Oral Biology

School of Dentistry

University of Louisville

Louisville, Kentucky

August 2005 
RIDGE AUGMENTATION COMPARING A CANCELLOUS BLOCK

ALLOGRAFT TO FREEZE DRIED BONE PARTICLES AND UTILIZING AN

ACELLULAR DERMAL MATRIX BARRIER MEMBRANE

By

Brenton Lahey

D.M.D., Temple University, 2002

A Thesis Approved on

June 29, 2005

By the following Thesis Committee:

Thesis Director 


\section{DEDICATION}

This manuscript is dedicated to my wife Amy. You are my best friend in the world, and I look forward to a lifetime of happiness together. You have supported me in countless ways over the last two and a half years, and I feel lucky to be with you. 


\section{ACKNOWLEDGEMENTS}

I would like to express my sincere gratitude to the following individuals:

Dr. Henry Greenwell, Program Director of Graduate Periodontics, for being a true mentor during my work on this thesis and my residency in periodontics. I am proud to have received my training from him.

Dr. Margaret Hill, Assistant Program Director, for the enthusiasm and encouragement she brings to the dental school on a daily basis.

Dr. James Scheetz, Ph.D., Statistician, for his guidance as my statistics professor and his assistance with the analysis of the data from this study. 


\author{
ABSTRACT \\ RIDGE AUGMENTATION COMPARING A CANCELLOUS BLOCK ALLOGRAFT \\ TO FREEZE DRIED BONE PARTICLES AND UTILIZING AN ACELLULAR \\ DERMAL MATRIX BARRIER MEMBRANE \\ Brenton Lahey, DMD
}

June 29, 2005

Aims. The primary aim of this randomized, controlled, blinded clinical trial was to compare the clinical and histologic results of ridge augmentation comparing a cancellous block allograft to a particulate mineralized freeze dried bone allograft using acellular dermal matrix as a barrier membrane.

Methods. Twenty-four patients that met the following inclusion criteria were sequentially entered into the study: 1) at least age $18 ; 2$ ) had at least a one tooth ridge defect treatment planned to receive a dental implant; 3) the defect was bordered by at least one tooth; and 3) an IRB approved informed consent was signed. Twelve test patients received a freeze dried bone particulate graft packed around supporting screws while 12 positive control patients received a cancellous block allograft immobilized with 1 or 2 screws. Following elevation of a superficial split-thickness flap, horizontal ridge dimensions were measured with a digital caliper at the crest and $5 \mathrm{~mm}$ apical to the crest. 
Vertical ridge dimensions were measured from a tooth-supported stent. At 4 month reentry a $2.7 \times 6 \mathrm{~mm}$ trephine core was obtained prior to implant placement.

$\underline{\text { Results. }}$ The crestal ridge width of the particulate group increased from $4.4 \pm 1.0 \mathrm{~mm}$ to $7.7 \pm 1.5 \mathrm{~mm}$ for a mean gain of $3.3 \pm 1.1 \mathrm{~mm}(\mathrm{p}<0.05)$ while the cancellous block cases increased from $3.3 \pm 0.9 \mathrm{~mm}$ to $7.1 \pm 1.0 \mathrm{~mm}$ for a mean gain of $3.8 \pm 1.3 \mathrm{~mm}(\mathrm{p}<$ $0.05)$. There was no significant difference between the two groups $(p>0.05)$. The width of the particulate group $5 \mathrm{~mm}$ apical to the crest increased from $6.9 \pm 1.1 \mathrm{~mm}$ to $9.7 \pm 1.7$ $\mathrm{mm}$ for a mean gain of $2.9 \pm 1.0 \mathrm{~mm}(\mathrm{p}<0.05)$ while the cancellous cases increased from $5.6 \pm 1.1 \mathrm{~mm}$ to $9.0 \pm 1.2 \mathrm{~mm}$ for a gain of $3.4 \pm 1.0 \mathrm{~mm}(\mathrm{p}<0.05)$. There was no significant difference between the two groups $(\mathrm{p}>0.05)$. The vertical component of the ridge defects was minimal, therefore, there was negligible gain of ridge height. Implants were placed as treatment planned in $12 / 12$ or $100 \%$ of the cancellous block cases, Implants were placed as treatment planned or with a larger diameter in $12 / 12$ or $100 \%$ of the particulate cases. Histologic analysis of the implant sites revealed $51 \pm 18 \%$ vital bone for the cancellous block group and $58 \pm 12 \%$ for the particulate group. Non-vital bone was $11 \pm 9 \%$ for the cancellous block group and $9 \pm 7 \%$ for the particulate group. Conclusions. There were no clinically or statistically significant ridge dimension differences between the particulate or cancellous block allograft groups. Histologic results also revealed minimal differences between groups. 


\section{TABLE OF CONTENTS}

\section{PAGE}

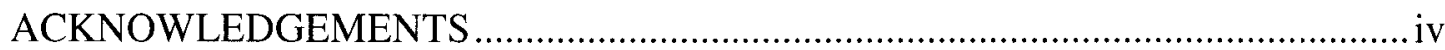

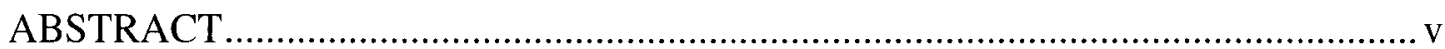

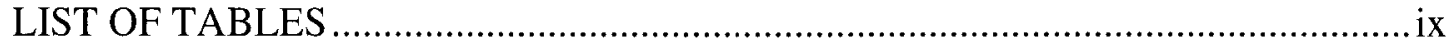

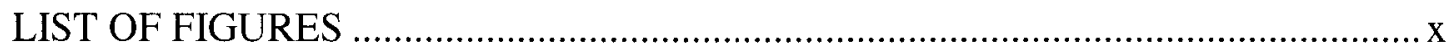

\section{CHAPTER}

\section{LITERATURE REVIEW}

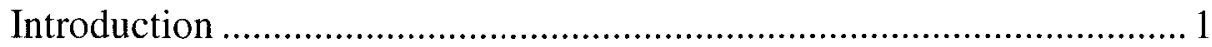

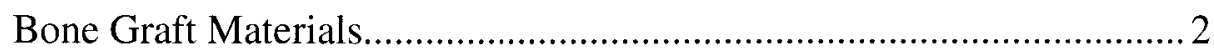

Membranes and Guided Bone Regeneration ........................................... 9

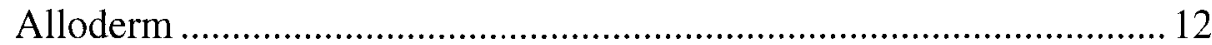

Guided Bone Regeneration Technique ............................................... 15

Implant Success in Regenerated Bone............................................... 21

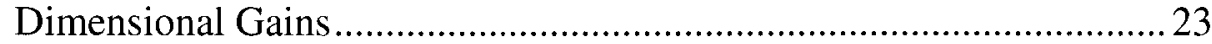

Graft Comparisons ............................................................................... 26

II. MATERIALS AND METHODS

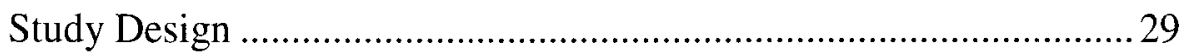

Patient Selection: Inclusion and Exclusion Criteria .............................. 30

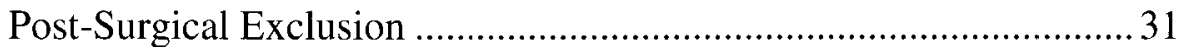

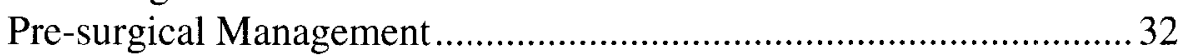

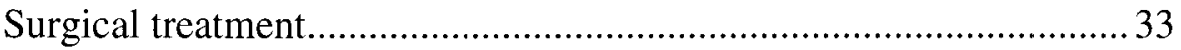

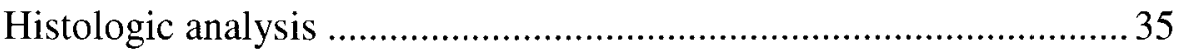

Statistical analysis............................................. 35

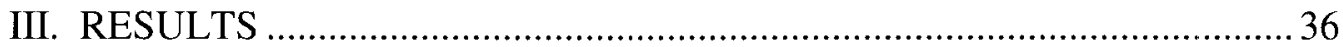

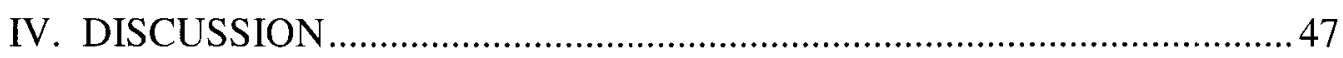

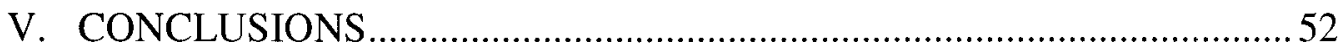

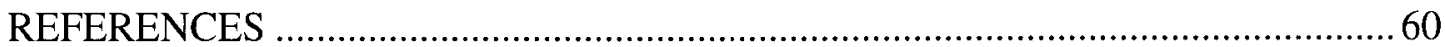




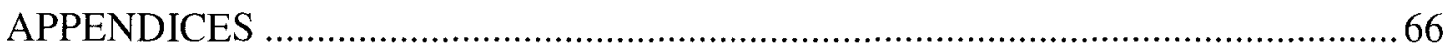

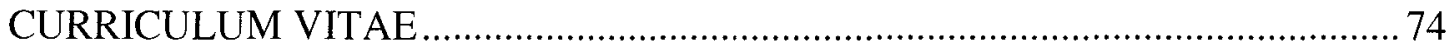




\section{LIST OF TABLES}

1. Urist (1976) Stages of Bone Graft Healing............................................................ 3

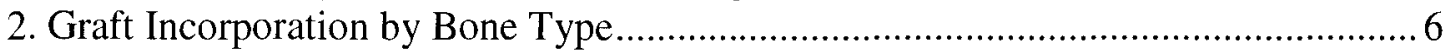

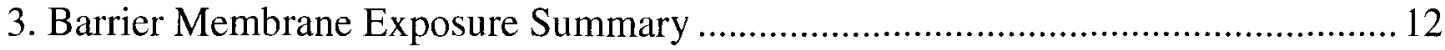

4. Buser et al. (1993) prerequisites for predictable GBR procedures ........................... 16

5. Albrektsson's Criteria of Implant Success (Albrektsson et al. 1986) ........................ 22

6. Albrektsson's Revised Criteria of Implant Success (Roos et al. 1997) ..................... 22

7. Barrier Membrane Alone Horizontal Augmentation ............................................ 24

8. Barrier Membrane plus Allograft Horizontal Augmentation......................................25

9. Barrier Membrane plus Allograft Vertical Augmentation........................................25

10. Histomorphometric Summary Analysis I...............................................................2 26

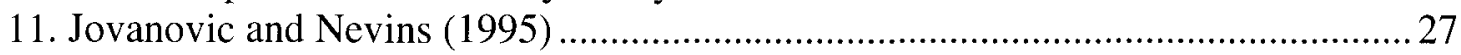

12. GBR Horizontal Augmentation Summary ..........................................................2. 28

13. Ridge Width Changes at the Crest for Block and Particulate Allograft Sites .......... 39

14. Ridge Width Changes $5 \mathrm{~mm}$ Apical to the Crest for Block and Particulate Allograft 40

15. Loss of Augmented Ridge Width for Block and Particulate Allograft Sites ........... 41

16. Ridge Height Changes Relative to a Stent for Block and Particulate Sites .............42

17. Histologic Data for Block and Particulate Groups ...................................................43

18. Predictability of Planned Implant Placement Entirely Within Hard Tissue.............. 44

19. Soft Tissue Thickness Changes for Block and Particulate Sites .............................. 45

20. Clinical Indices for Block and Particulate Sites .......................................................46

21. Soft Tissue Thickness Changes in Preservation/Augmentation Sites ......................53 


\section{LIST OF FIGURES}

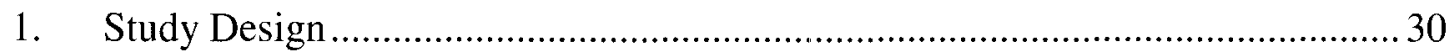

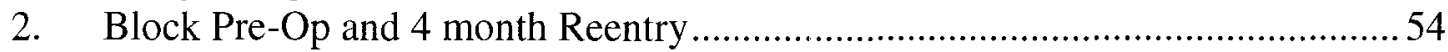

3. Paticulate Pre-Op and 4 month Reentry......................................................56

4. Vital Bone with Non-Vital Block Bone ...........................................................58

5. Non-Vital Particulate Bone and Vital Bone.....................................................58

6. Mature Vital bone with amorphous organic matrix ...........................................59

7. Vital bone and Vascular Channels ..................................................................59 


\section{CHAPTER I}

\section{LITERATURE REVIEW}

\section{Introduction}

In dentistry today there is a great demand for restoring edentulous areas with dental implants. Through years of clinical experience and research, along with improvements in dental materials, implants have become a very predictable procedure. However, implant placement requires an adequate amount of bone in both the horizontal and vertical dimensions. Through various processes including tooth extraction and trauma the required bone is often lost. Even if there is enough bone present to place an implant at a given site, it often is not in the correct location for ideal esthetic implant placement. Various bone regenerating techniques have been developed to help establish proper ridge position and dimensions. These procedures include bone grafting alone, distraction osteogenesis, and guided bone regeneration.

Guided bone regeneration (GBR) refers to the use of membranes to regenerate bone in desired areas. The idea is based on the theory that the cells responsible for creating new bone migrate into the wound more slowly than cells responsible for the formation of connective tissue. The membrane serves as a barrier to connective tissue cells and results in new bone formation.

To enhance the amount of new bone the GBR principle was combined with the use of bone grafts. Autogenous bone grafts had been used successfully without 
membranes to graft alveolar defects, and they became the bone graft material of choice for much of the early work done on guided bone regeneration. However, the downfalls of autogenous grafting such as donor site morbidity and limited supply forced clinicians and researchers to look for other grafting materials such as allografts, xenografts, and alloplasts. There has been a great deal of research on the different types of allografts in terms of bone type and graft form (Burchardt 1983, Zins and Whitaker 1983, Ozaki and Buchman 1998). Today many allografts materials have been proven to be just as effective as autogenous grafts when used for guided bone regeneration (Nevins and Mellonig 1992, Shanaman 1992, Nevins and Mellonig 1994).

In addition to the bone graft material options, there are also many different types of membranes that can be used. The membranes generally fall into two broad categories. The first is non-resorbable membranes that must be removed during a subsequent surgical procedure. The second is resorbable membranes that are eventually infiltrated and broken down by the surrounding soft tissue. Each group has its own advantages and disadvantages, but both have been successfully used for guided bone regeneration procedures.

The technique of guided bone regeneration has evolved over the past 15 years or so as clinicians have tried to increase its predictability. However many of the basic principles that were described by Dahlin et al. (1988) still hold true today.

\section{Bone Graft Materials}

One of the main principles of ridge augmentation procedures is space maintenance (Buser et al. 1993). The area of desired bone growth will be acted on by a 
variety of forces within the mouth. In order for the ridge augmentation to be successful those forces cannot be allowed to collapse the space created for bone growth. One of the main downfalls of placing a membrane around an area without some sort of rigid support system is that it may fail to maintain its desired shape due to the forces put upon it. This results in less than desired bone growth. To combat this problem various titanium frameworks or meshworks have been added to, or used underneath the membranes. Another method used to combat this problem is the placement of a bone graft either under a membrane or by itself. The bone graft, especially in a rigid block form, can not only be resistant to external forces, but also offer osteoconductive, osteoinductive, and osteogenic properties that promote bone growth. It is generally accepted that the more rigid block forms offer better mechanical space maintenance properties than the particulate graft materials. The question could then be asked whether that makes a difference in terms of the amount of new bone created through a ridge augmentation procedure.

A bone graft, whether allogeneic or autogenous, goes through several stages of healing after a ridge augmentation procedure. Urist (1976) described five stages of incorporation of a bone graft.

Table 1

Urist (1976) Stages of Bone Graft Incorporation

\begin{tabular}{|c|c|c|c|c|}
\hline Stage 1 & Stage 2 & Stage 3 & Stage 4 & Stage 5 \\
\hline Inflammation & Osteoblasts & Osteoinduction & Osteoconduction & $\begin{array}{c}\text { Biomechanical } \\
\text { supporting } \\
\text { structure }\end{array}$ \\
\hline
\end{tabular}


The first stage is an inflammatory one where the breakdown of the bone graft materials causes a chemotactic response. Mesenchymal cells that will differentiate into osteoblasts and osteoclasts migrate to the area. The second and third stages are characterized by osteoinduction. Urist (1976) defines osteoinduction as the process of differentiation of fibroblast-like migratory mesenchymal cells into osteoprogenitor cells on calcified tissue matrices that are demineralized in the course of resorption. The process of osteoinduction is mediated largely by proteins called bone morphogenic proteins or BMPs. Urist (1976) states that when an allograft is sterilized by autoclaving or irradiation the osteoinductive properties of the graft are lost. There are bone morphogenic proteins present in allografts (Goldberg and Stevenson 1987). It has been suggested that by demineralizing an allograft (demineralized freeze dried bone allograft, DFBDA) the bone morphogenic proteins are exposed and that leads to osteoinduction by the allograft. However, it is a matter of debate as to whether or not the BMPs in sterilized allografts lead to osteoinduction. In this study the two allografts probably have little osteoinductive capability, and so stages 2 and 3 graft incorporation are largely absent. Stage four of the incorporation process is characterized by osteoconduction, which refers to the ingrowth of vascular channels and bone forming cells from the host onto the graft tissue. Since osteoinduction plays a minor role at best in sterilized allografts, osteoconduction is the major component of the graft incorporation. Finally stage five of graft incorporation as described by Urist (1976) is predominantly a mechanical one where the graft acts as biomechanical support structure for bone remodeling. 
While bone grafts of cancellous and cortical origin share common stages of graft incorporation, they have some important differences within those stages. Goldberg and Stevenson (1987) published a review article on allograft and autografts where they discuss these differences. In cancellous bone grafts the incorporation process is characterized by a rapid revascularization and resorption of non-vital graft material. The structure of the cancellous bone acts as a framework or "trellis" for vascular ingrowth from the host tissue. Osteoblasts populate the graft and deposit a layer of osteoid that surrounds a portion of the non-vital allograft. Urist (1976) termed this process incorporation. This new bone that is laid down with the cancellous graft leads to an initial increase in the density of the graft. The increased density leads to an initial increase in the mechanical strength of the cancellous graft. This could be a possible advantage of cancellous grafts in the early stages of graft healing. As the graft matures the necrotic bone is resorbed and the density of the grafted area returns to normal. This overall process of new bone surrounding non-vital graft that is eventually resorbed and replaced is termed creeping substitution. Over time creeping substitution leads to complete resorption of a cancellous graft.

Cortical grafts are incorporated into a recipient site by a fundamentally different process than that of cancellous grafts. Urist (1967) termed the process of cortical graft incorporation "reverse creeping substitution". Cortical grafts are not nearly as porous as cancellous grafts initially. For vascular ingrowth or osteoconduction to occur some of the cortical graft is first resorbed by osteoclasts. This leads to a much slower vascularization process in cortical grafts as compared to cancellous grafts. Thus, the osteoconduction process of the cortical graft starts with an osteoclastic response. This is the opposite of 
the cancellous grafts, which begin osteoconduction with an osteoblastic response. The result is that while cancellous grafts become denser during the early stages of healing, cortical grafts become less dense. This leads to an initial decrease in the mechanical strength of cortical bone grafts (Burchardt 1983). Finally, cortical bone grafts are not completely resorbed like cancellous grafts. Instead, they can remain a mixture of new vital bone and nonvital graft particles for many years.

\section{Table 2}

\section{Graft Incorporation by Bone Type}

\begin{tabular}{|l|l|}
\hline Cancellous Bone Graft Incorporation & Creeping Substitution \\
\hline Cortical Bone Graft Incorporation & Reverse Creeping Substitution \\
\hline
\end{tabular}

While the structural aspects of a graft (cortical vs. cancellous) could play a role in the healing of a graft, other research has focused on the embryologic origin of the graft. Smith and Abramson (1974) studied autografts that were either membranous or endochondral in a rabbit model. Bone forms by two basic mechanisms in the body. Endochondral bone formation involves the calcification of cartilage, and intramembranous bone formation involves a direct transition from connective tissue to bone. The endochondral block grafts were obtained from the ilium and the membranous grafts from the skull. What they found was that the endochondral grafts lost a significantly larger portion of their initial volume than the membranous grafts. They postulated that this result was due to a difference in the normal stress levels placed on the different types of bone. The endochondral bone of the ilium was normally subjected to more stress then the membranous skull bone. When the endochondral bone was grafted 
to a site where there was less stress it resorbed. They also hypothesized that since the endochonral bone had a larger cancellous content, it was easier for connective tissue vascularity to penetrate and resorb.

Zins and Whitaker (1983) repeated the work of Smith and Abramson (1974) with the same results. They used both a rabbit and monkey model to conclude that membranous bone was superior for craniofacial grafting. They hypothesized that the reason for this was either a more rapid revascularization of the endochondral bone, or a delayed vascularization leading to slower resorption of the endochondral bone. Since endochondral bone has a larger cancellous component, it seems the latter is more likely based on the previously discussed work by Goldberg and Stevenson (1987).

Ozaki and Buchman (1998) hypothesized that the success or failure of a block graft was not based on its embryologic origin, but on whether it was cancellous or cortical bone. They felt that the earlier results of Smith and Abrams were because the membranous grafts were primarily cortical bone and the endochondral grafts were a mix of cancellous and cortical bone. To test this hypothesis they used the same rabbit model to compare cortical and cancellous block grafts both of endochonral origin. They found significantly greater resorption of the cancellous grafts. In addition they compared cortical block grafts from endochonral bone to those taken from membranous bone and found no difference in the amounts resorbed. From this study they concluded that cortical block grafts were superior to cancellous block grafts. However, these studies were looking at autogenous onlay grafts meaning that no membrane was used. Therefore unlike guided bone regeneration where the cells of the surrounding connective tissue are blocked by a membrane, these connective tissue cells had direct access to the grafts. The 
less permeable cortical bone would offer greater resistance to connective tissue penetration and resorption of the graft.

There is very little in the literature about cancellous block allografts for ridge augmentation procedures. Leonetti and Koup (2003) published a report of four cases of ridge augmentations with a cortico-cancellous block allograft (Puros J-block). The blocks were shaped, secured in place with a titanium screw, and covered with a Biomend collagen membrane (Centerpulse). All of the sites were reentered at 6 months and implants were successfully placed and restored. Histology was obtained from one graft site that showed vital bone with no residual graft material.

Keith (2004) also published a case report on the use of a cortico-cancellous block allograft (Puros J-block) used for ridge augmentation. He reentered the grafted site after four months of healing and found very little loss of the initially grafted dimensions. The initial ridge width of $3 \mathrm{~mm}$ was increased to $9 \mathrm{~mm}$ for a gain of $6 \mathrm{~mm}$. A wide diameter implant was successfully placed in the site.

The only report of an entirely cancellous block allograft for ridge augmentation was done by Lyford et al. (2003). He reported on five cases of ridge augmentations using the same cancellous block allograft material that was used in this study. The blocks were shaped, secured, and covered by either non-resorbable or resorbable membranes. $\mathrm{He}$ showed a mean initial ridge width of $3.4 \mathrm{~mm}$ that increased to $6.0 \mathrm{~mm}$ at 6 month reentry. Unfortunately, no histology was obtained in his study. 


\section{Membranes and Guided Bone Regeneration}

The idea of using a membrane to produce bone growth has it roots in orthopedic surgery. Hurley et al. (1959) described using a Millipore filter to guide bone growth in spinal fusion procedures. Membranes got their start in periodontics for use in guided tissue regeneration procedures (Gottlow et al. 1984). Several years later membrane use would be applied to ridge augmentation procedures. The concept of using a membrane to promote bone growth in the mouth was developed by Dahlin et al. (1988). The hypothesis was that the cells responsible for creating new bone in the body migrated to a wound site at a slower rate than the fibroblasts of the surrounding soft tissue. Therefore, if the site of desired bone growth was walled off, then only bone producing cells had access, and the wound site would fill entirely with new bone rather than soft tissue. Conversely, if the site were left exposed, the faster migrating gingival fibroblasts would repopulate the site first producing predominantly soft tissue. This idea had its roots in results from earlier studies that were using membranes to try to regenerate lost periodontium around diseased roots (Gottlow et al. 1984). Gottlow et al. (1984) stated that if bony defects around diseased roots were repopulated only by cells from the periodontal ligament and not the gingival connective tissue and epithelial cells, then a new attachment apparatus (new cementum, new bone, and new functionally oriented periodontal ligament) would form in the defect site. Dahlin et al. (1988) used the same idea of a mechanical barrier or membrane to block unwanted cells. The difference was that the goal was not to regenerate a new periodontal apparatus. Instead, the goal was to create new bone only. Buser et al. (1993) would later use the term guided bone regeneration to show that the membrane was being used to regenerate bone by itself, 
while guided tissue regeneration referred to regenerating a new periodontal apparatus around a diseased root.

Dahlin et al. (1988) began their work with guided bone regeneration by creating through and through bony defects in the mandibles of rats. The defects were produced bilaterally, with one defect covered on both sides by an expanded polytetrafluoroethlyene (ePTFE) membrane. The defect on the contralateral side was left open so that when the flaps were sutured the connective tissue of the flap had direct access to the defect. Complete bone fill only occurred in the groups where membranes were placed over the surgically created defects. Some bone was created in the control defects but was always intermixed with a large amount of fibrous tissue (Dahlin et al 1988). Dahlin et al. (1990) then conducted a similar study in monkeys in an effort to demonstrate the membrane effect in an animal model biologically closer to a human. Through and through defects were created in the mandibles and periapical defects were created in the maxilla. The results were very similar to their previous study in rats. Complete bone fill of the surgically created defect was obtained in the sites that were protected by a barrier membrane.

Dahlin et al. (1988) used a non-resorbable ePTFE membrane that remains a popular membrane for guided bone regeneration procedures. The membrane is designed with pores large enough to allow the passage of fluid and nutrients, but small enough that the fibroblasts responsible for fibrous tissue formation are blocked. Since the membrane material is not resorbed by the body, it provides a barrier function for as long as it is in place at the defect site. The longevity of its barrier function is considered one of the great advantages of a non-resorbable membrane. The obvious drawback of a non-resorbable 
membrane is the need for a second surgical procedure to remove the membrane. This is not a concern for guided bone regeneration procedures for implant site development, since a second surgery will already be necessary to place the implants. However, many GBR procedures are done at the time of implant placement or for esthetic purposes in fixed partial denture cases. To avoid a second surgical procedure, resorbable membranes were developed and tested (Sandberg et al. 1993). Sandberg et al. (1993) repeated the experimental design that Dahlin et al. (1988) had used earlier, only this time the contralateral defects were used to compare a resorbable membrane (polylactic/polyglycolic acid copolymers) vs. a non-resorbable membrane (ePTFE). Both membranes led to comparable amounts of bone fill.

A major disadvantage of non-resorbable barriers is the increased incidence of wound dehiscence. Zitzmann et al. (1997) compared ridge augmentation procedures in twenty-five patients using a split mouth design where one defect was treated with a resorbable collagen membrane while the other received a non-resorbable membrane. The mean bone fill was $92 \%$ for the resorbable sites and $78 \%$ for the non-resorbable sites. The incidence of wound dehiscence and membrane exposure was $16 \%$ for the resorbable group and $24 \%$ for the non-resorbable group. At the six week exam that number had fallen to $9 \%$ in the resorbable group, but in the non-resorbable membranes group all of the dehiscences were still present. Zitzmann et al. (1997) then evaluated the effect of membrane exposure on the amount of bone fill. Simion et al. (1994) had previously reported decreased bone fill in GBR procedures with exposed ePTFE membranes. Zitzmann et al. (1997) found that there was $94 \%$ bone fill in the resorbable membrane group where the membrane did not become exposed vs. $87 \%$ when the membrane was 
still exposed at six weeks. In the non-resorbable group the percent bone fill was $98 \%$ at the unexposed sites and $65 \%$ at the exposed sites.

\section{Table 3}

\section{Barrier Membrane Exposure Summary}

\begin{tabular}{|l|c|c|c|}
\hline \multicolumn{1}{|c|}{ Author/Year } & $\begin{array}{c}\text { Total } \\
\text { Cases }\end{array}$ & $\begin{array}{c}\text { Cases } \\
\text { Exposed }\end{array}$ & Percent Exposed \\
\hline Buser et al. 1990 & 12 & 2 & $17 \%$ \\
\hline Nevins and Mellonig 1992 & 3 & 2 & $66 \%$ \\
\hline Simion et al. 1992 & 1 & 5 & $20 \%$ \\
\hline Nevins and Mellonig 1994 & 4 & 4 & $100 \%$ \\
\hline Becker et al. 1994 & 3 & 2 & $66 \%$ \\
\hline Fugazzotto 1998 & 296 & 77 & $29 \%$ \\
\hline Chiapasco et al. 1999 & 15 & 2 & $13 \%$ \\
\hline Mattout and Mattout 2000 & 214 & 26 & $12 \%$ \\
\hline Assenza et al. 2001 & 22 & 4 & $18 \%$ \\
\hline Friedmann et al. 2002 & 14 & 10 & $71 \%$ \\
\hline Knapp et al. 2003 & 12 & 6 & $50 \%$ \\
\hline Chiapasco et al. 2004 & 11 & 3 & $27 \%$ \\
\hline
\end{tabular}

\section{Alloderm}

A material that has been used more recently as a barrier membrane is acellular dermal matrix or Alloderm. Alloderm is a soft tissue allograft material that is derived from cadaveric skin. The skin is harvested and then first treated to separate the epidermal cells from the dermal cells leaving the dermis layer and an intact basement membrane. From there the tissue is treated with a non-denaturing detergent that removes the cells of the tissue without disrupting the extracellular matrix that surrounds them. What remains is an acellular dermal matrix graft that facilitates revascularization and new tissue 
formation at the recipient site. To preserve the tissue for later use the acellular dermal matrix is put through a patented freeze drying process that does not damage the extracellular matrix.

Alloderm was originally developed as a skin allograft for burn patients. Previously used skin allografts were eventually rejected due to the foreign cells of the graft. In response to that problem this acellular dermal matrix was developed (Wainwright et al. 1996). Since that time Alloderm has been used for various other surgical procedures including, gingival augmentation and root coverage procedures in periodontal surgery (Henderson et al. 2001, Harris 1998), and as a repair mechanism for flap fenestrations with bone grafting procedures (Batista and Batista 2001).

The acellular dermal matrix can be used as a barrier membrane for ridge augmentation (Johnston 2003). The downfall of some resorbable membranes is too rapid a resorption time. If the membrane is broken down and penetrated by gingival fibroblasts too quickly in the healing phase, it could compromise the amount of new bone that is regenerated. Eppley (2001) studied how quickly Alloderm revascularized when it was placed in a subcutaneous pouch in a rabbit ear. It was completely vascularized after two weeks healing and penetration of the blood vessels occurred equally fast on both the basement membrane and connective tissue sides of the Alloderm. Two things could potentially change the rate of revascularization in a ridge augmentation procedure for a human patient as compared to Eppley (2001). The first is the potential healing differences between a human and the rabbit. The second is that in a guided bone regeneration model the revascularization occurs from only the soft tissue side of the 
Alloderm and has to penetrate the full thickness of the membrane to reach the grafted area.

Wainwright et al. (1996) did histology on burn sites in humans that were grafted with Alloderm and then covered with a skin autograft. The histology at two weeks post surgery showed vascular penetration from the bed site to but not into the basement membrane (the Alloderm was placed with the connective tissue side facing the recipient site). In addition fibroblasts had also penetrated the Alloderm to, but not into, the basement membrane complex. This study has an advantage over Eppley (2001) in that it is human histology and not animal histology, but it is still difficult to say how applicable it is to a guided bone regeneration procedure in the mouth. Thus there is not much in the literature upon which one can base a statement of how long Alloderm would prevent gingival fibroblast penetration into a guided bone regeneration site. In fact there are only two randomized controlled studies that used Alloderm as a barrier membrane (Johnston 2003, Cordini 2004)

Johnston (2003) compared the barrier membrane effect of Alloderm to ePTFE in the treatment of class II furcation defects. No differences between the two membranes were reported, which showed Alloderm was successful as a barrier membrane in those procedures. Cordini (2004) used Alloderm GBR as a membrane for guided bone regeneration. Alloderm GBR is a thinner version of the standard Alloderm product specialized designed for guided bone regeneration procedures. Cordini (2004) found significant gains in horizontal ridge width using an Alloderm GBR membrane.

There are several case studies that report the use of Alloderm as a barrier membrane. Novaes and Souza (2001) used Alloderm as a barrier membrane for a ridge 
preservation procedure on site number 11 on a 48 year old woman. Upon reentry 6 months later new bone had formed allowing the placement of a $5.5 \times 10 \mathrm{~mm}$ implant. Fowler et al. (2000) reported two successful cases of ridge preservation using Alloderm as a barrier membrane. Later that same year Fowler et al. (2000) published part two of that study where he presented a case report on an immediate implant placement and simultaneous guided bone regeneration around the implant using Alloderm as a membrane. The implant was placed and the GBR procedure was considered a success. Finally, Griffin et al. (2004) reported two ridge preservation cases using Alloderm as a membrane where implants were successfully placed 3 to 4 months later. He also reported a case where Alloderm was successfully used as a membrane in a guided bone regeneration procedure designed to cover a non-restorable implant.

Based on randomized controlled trials and case reports there is support for the use of Alloderm as a barrier membrane in guided bone regeneration procedures.

\section{Guided Bone Regeneration Technique}

Dahlin et al. (1988) were the pioneers of guided bone regeneration, but it was Buser et al. (1990) and Nyman et al. (1990) that began the description of its technique in clinical practice. Buser et al. (1990) published technique articles for ridge augmentation in the maxilla (Buser et al. 1993) and the mandible (Buser et al. 1995). He outlined four prerequisites for predictable success with ridge augmentation procedures. 


\section{Table 4}

\section{Buser et al. (1993) prerequisites for predictable GBR procedures}

1. Achievement of primary soft tissue closure and healing

2. Use of an appropriate barrier membrane

3. Stabilization and close adaptation of the membrane to the surrounding bone

4. Creation and maintenance of a secluded space

The first was the achievement of primary soft tissue closure and healing to avoid membrane exposure. The second was selection of the appropriate membrane. Buser et al. (1993) felt this was a non-resorbable membrane in the case of GBR procedures because a reentry procedure for implants was always necessary. The third was stabilization and close adaptation of the membrane to the surrounding bone. This was necessary to prevent ingrowth of connective tissue cells into the defect. Finally Buser et al. (1993) said that creation and maintenance of a secluded space was needed. He accomplished this by using tenting screws to hold out the membrane and by using filler materials hold out the membrane. Buser et al. (1993) first used collagen and then later switched to autogenous bone as the filler material. In addition to these prerequisites he later added surgical recommendations including; 1) perforation of the cortical bone plate to achieve a bleeding bone surface; 2) using an appropriate bone-filling material for blood clot stabilization; 3) fix and stabilize the membrane with fixation screws to prevent micromovement; and 4) the use of horizontal mattress and interrupted sutures to obtain tension free primary closure (Buser et al. 1995). 
One of Buser et al. (1993) four prerequisites for a successful guided bone regeneration procedure is primary closure of the graft site. He describes making periosteal releasing incisions to obtain primary flap closure when suturing. He then later qualifies this prerequisite by saying that the primary closure should be obtained without tension at the flap margins. Seibert (1993) advocated tension free closure because he felt that tension on the flap would lead to collapse of the membrane thereby violating one of Buser's other prerequisites space maintenance. Another, possibly more important reason for tension free flap closure is to prevent failure of flap union and subsequent membrane exposure. In a review by Machtei (2001) the decreased effectiveness of guided bone regeneration if membrane exposure occurs was discussed. Bahat and Koplin (1989) described a "pantographic flap" that allowed coronal advancement and tension free closure of flaps during ridge augmentation procedures. More recently Greenwell et al. (2004) described a superficial split thickness flap for tension free closure. The advantage of the flap is extreme flap release that allows complete, passive flap coverage for virtually all ridge augmentation procedures. In addition, the flap creates an absence of muscle pull during healing, which prevents flap retraction and promotes wound closure. This is accomplished by sharp dissection of the flap to separate the epithelium and connective tissue layers from the underlying muscle and periosteum. This is in contrast to a traditional split thickness flap that separates the periosteum from the muscle layer. This leaves the muscle attachments to the flap and allows for pull on the flap during lip and cheek movements.

As mentioned earlier one of the primary reasons for having tension free closure of the flap is to avoid membrane exposure. There are a multitude of studies and case reports 
documenting incidence of membrane exposures with guided bone regeneration procedures. Table 1 lists many of these articles and the corresponding percentages. Machtei (2001) published a meta analysis on GBR studies that documented membrane exposures and the amount of bone formation that resulted. The two studies that met the inclusion criteria had a mean of $3.01 \mathrm{~mm}$ of new bone in the cases where no membrane exposure occurred vs. $0.56 \mathrm{~mm}$ in the cases where membrane exposure occurred. Simion et al. (1994) reported less bone formation around immediate implant sites with simultaneous GBR that became exposed. He found $41.6 \%$ graft take in the exposed membrane group vs. $96.6 \%$ in the non-exposed group. Clearly membrane exposure has a significant negative effect on the outcome of ridge augmentation.

Buser et al. (1993) recommended making perforations in the cortical plate of the graft site with a small round bur. This created a bleeding bone surface that enhanced the outcome of the guided bone regeneration procedure. Two animal studies support this recommendation. The first was by Majzoub et al. (1997) where the bone was analyzed histologically. A titanium dome was attached to rabbit skulls and test sites had cortical perforations made in the areas covered by the domes while the control sites did not. Bone neogenesis was quicker and greater in quantity and density in the sites with cortical perforations. They hypothesized that the cortical perforations allowed for a quicker migration of bone forming cells from the medullary spaces to the site of bone formation. They also hypothesized that the injury to the cortical plate caused a release of bone morphogenic proteins. Carvalho et al. (2000) did a similar study in dogs with autogenous onlay grafts. He studied three different types of bed preparations. The first was an unperforated cortical plate, the second a perforated cortical plate, and the third a 
decorticated plate. Histology showed poor incorporation of the grafts at the cortical plate sites, and good integration of the grafts on the perforated and decorticated sites. Thus both of these studies support Buser et al. (1993) recommendation that cortical perforations be made at the recipient graft site.

One of Buser et al. (1993) prerequisites was the close adaptation and fixation of the membrane. The close adaptation of the membrane is needed to ensure exclusion of connective tissue cells. The fixation of the membrane leads into the idea of wound stability. A stable fibrin clot in the area of desired bone growth is crucial to new bone formation. Wikesjo and Nilveus (1990) and Haney et al. (1993) explored wound stabilization and its effects on healing guided tissue regeneration procedures. They used animal models to conclude that wound stabilization was an important part of the healing in GTR. Since GBR and GTR work on many of the same principles it seems reasonable to conclude that wound stabilization is important for ridge augmentation procedures as well.

Buser et al. (1993) recommended a healing period of nine months for GBR procedures. Fugazzotto (1998), in a report on 302 consecutive ridge augmentation procedures, stated that the sites were reentered anywhere from four to ten months after grafting. In this study Gore-Tex membranes were used with various nonautogenous particulate grafts. He noted that the later the reentry the more mature the bone appeared. In another study by Fugazzotto and De Paoli (1999) they looked at the dimensional stability of ridge augmentation sites underneath pontic sites. Titanium reinforced GoreTex membranes were used with either DFDBA+ tricalcium phosphate or Bio-Oss. Bone sounding was done as far out as thirty months post augmentation. They reported a 
change of less than $0.1 \mathrm{~mm}$ in the buccopalatal dimension over the 30 month observation period. This supported longer periods of healing prior to reentry. However, in a clinical setting, patient demands for timely restoration may not allow for such long reentry times. As long as the reentry time is not so short that it compromises the success of the implants, shorter reentry times than the 9 months Buser et al. (1993) recommended seem reasonable.

Another technical aspect of ridge augmentation procedures that Buser did not address was rigid fixation of block grafts. Lin et al. (1990) did a study on autogenous block grafts placed in one of two locations in a rabbit model. The grafts were placed either in an area where they would easily become mobile (femur), or in an area of relatively low mobility (snout). Blocks in each location were either rigidly fixated with a screw or loosely fixated with sutures. In the highly mobile femur recipient sites grafts that were rigidly fixated with a screw were much more successful. Since the oral cavity is a fairly mobile area of the body, with a multitude of muscle forces present at any given time, rigid fixation of block grafts with titanium screws seems advisable.

Another aspect of ridge augmentation technique that Buser et al. (1993) did not address, but that has been discussed by Misch (1999), is the use of a combination of different graft materials in GBR procedures. Misch termed this the "sandwich" bone augmentation technique or the layered approach to bone grafting. Misch describes the technique as something to be used when there was insufficient autogenous bone available intraorally. The inner layer of the graft, closest to the recipient bone site, was always autogenous bone. The second or intermediate layer was a mixture of DFDBA and calcium phosphate resorbable alloplasts plus PRP. The intermediate layer was then 
covered by either a resorbable or non-resorbable membrane depending on the time of desired barrier function. The calcium phosphate is needed for mineralization of new bone at the graft site, and the DFDBA and PRP provide bone morphogenic proteins that are needed for new bone formation. Wang et al. (2004) reported on five cases of ridge augmentation procedures where the graft used was three different layers of materials. The bottom layer was autogenous osseous coagulum, the middle layer was DFDBA particles, and the top was bovine derived HA. The technique was used around dehiscence defects on implants. They reported a mean of $10.5 \mathrm{~mm}$ of bone formation and $100 \%$ defect fill. The rationale for this technique was that it allows the advantageous aspects of the different graft materials to be combined for a better overall result in GBR procedures. The osseous coagulum provides osteogenic properties not found in the other two grafts. The DFDBA is a readily available allogeneic material that can compensate for a lack of available autogenous bone, and the bovine HA is a slowly resorbing xenograft that will provide long term space maintenance properties. The idea of mixing different types of graft materials to exploit their individual advantages in GBR shows great promise based on the results of these case reports.

\section{Implant success in regenerated bone}

The ultimate goal for many guided bone regeneration procedures is successful implant placement. Several studies have examined the long term stability of implants placed in grafted bone. Fugazzotto (1997) evaluated success rates of 626 implants according to Albrektsson's criteria. 


\section{Table 5}

\section{Albrektsson's Criteria of Implant Success (Albrektsson et al. 1986)}

1. An individual, unattached implant is immobile when tested clinically.

2. A radiograph does not demonstrate any evidence of peri-implant radioloucency.

3. Vertical bone loss is less than $0.2 \mathrm{~mm}$ annually following the implant's first year of service.

4. Persistent or irreversible signs or symptoms, such as infection, pain, paresthesia, neuropathies, or violation of the mandibular canal, are absent.

5. Of the implants tested for the above mentioned criteria, $85 \%$ are proven successful after 5 years and $80 \%$ after 10 years in function.

Table 6

\section{Albrektsson's Revised Criteria of Implant Success (Roos et al. 1997)}

1. An individual, unattached implant is immobile when tested clinically

2. All implants must be individually radiographed and show no evidence of loss of integration

3. Bone loss is less than $1.0 \mathrm{~mm}$ in the first year, followed by less than $0.2 \mathrm{~mm}$ annually thereafter.

4. Severe adverse events, ie, complications resulting in changes of the treatment plan (Helsinki Declaration), are absent.

5. The percentage of implants falls within the stated range in the following categories: unaccounted for $<25 \%$; failures: $<10 \%$; success: $>80 \%$ of the surviving implants after 5 years in function.

All implants were placed in regenerated bone either at the time of grafting or months later using a staged approach. The observation period for the implants was up to 51 months after initial loading. There was a cumulative success rate of $93.8 \%$ overall, $94.9 \%$ in the maxilla, and $91.9 \%$ in the mandible. Nevins et al. (1998) also studied long term success rates of implants placed in regenerated bone. They reported on 526 implants placed in either at the time of grafting or later using a staged approach. Some of the grafts were 
done using autogenous bone, and some were done with allogeneic bone. The follow-up time ranged from 6 to 74 months post-loading. The overall success rate was $97.5 \%$. In addition there was no difference in the success rates of the implants placed in autogenous grafted bone compared to those placed in allograft bone. Fritz et al. (2001) evaluated the success of implants in regenerated bone from a histologic perspective. Implants were placed in monkeys in both native and regenerated bone and then loaded with a fixed prosthesis for one year. The same radiographic and histologic appearance was seen in both native bone and regenerated bone sites. Also, bone to implant contact showed no significant difference between the implants in native bone (59\%) and the implants in regenerated bone $(65 \%)$. Based on the results of these studies it is clear that implants placed in regenerated bone are just as successful as those placed in native bone.

\section{Dimensional Gains}

While the successful placement of an implant is the ultimate goal of many ridge augmentation procedures, the success is determined by the amount of new bone that can be generated by the procedure. Buser (1990) studied humans with an ePTFE membrane alone for ridge augmentations. The data from seven patients was reported as starting with a mean initial width of $3.6 \mathrm{~mm}$ that increased to a mean of $6.1 \mathrm{~mm}$ for a mean gain of $2.5 \mathrm{~mm}$ in ridge width. However, the range of gains in ridge width was from 0 to 5.5 $\mathrm{mm}$ showing a large variation in the results. 


\section{Table 7}

\section{Barrier Membrane Alone Horizontal Augmentation}

\begin{tabular}{|l|c|c|c|c|c|c|}
\hline Author & $\begin{array}{c}\# \\
\text { Cases }\end{array}$ & $\begin{array}{c}\text { Initial } \\
(\mathrm{mm})\end{array}$ & $\begin{array}{c}\text { Final } \\
(\mathrm{mm})\end{array}$ & $\begin{array}{c}\text { Change } \\
(\mathrm{mm})\end{array}$ & $\begin{array}{c}\text { Range } \\
(\mathrm{mm})\end{array}$ & Histology \\
\hline $\begin{array}{l}\text { Buser et al. } \\
1990\end{array}$ & 7 & 3.6 & 6.1 & 2.5 & $0-5.5$ & Yes \\
\hline
\end{tabular}

Buser et al. (1993) later recommended the addition of a bone graft or filler under the membrane to prevent the collapse seen in his earlier study. Feuille et al. (2003) reported on ridge augmentations in ten patients using titanium reinforced membranes and FDBA. At six month reentry $69 \%$ of the grafted horizontal dimension had been lost and nearly all of the grafted vertical dimension was lost. The mean initial width was 4.25 $\mathrm{mm}$. The mean width at reentry was $7.4 \mathrm{~mm}$ for a gain of $3.2 \mathrm{~mm}$. The vertical gain was $0.4 \mathrm{~mm}$. The histology in this study showed a range of 43 to $70 \%$ new bone formation for a mean of $48 \%$. Residual graft particles represented from 30 to $57 \%$ of the biopsy cores for a mean of $52 \%$.

Kaufman et al. (2003) reported two cases of ridge augmentations with titanium reinforced ePTFE membranes and a mixture of autogenous bone cores and DFDBA. At five month reentry one site gained $4 \mathrm{~mm}$ in ridge height and the other site gained $5 \mathrm{~mm}$ of ridge height. That corresponded to a mean vertical gain of $4.5 \mathrm{~mm}$.

Lyford et al. (2003) reported on three ridge augmentation procedures using either a BioMend Extend or ePTFE membrane combined with a cancellous block allograft. The mean initial ridge width was $3.4 \mathrm{~mm}$. At reentry 6 months later it was a mean of $6.0 \mathrm{~mm}$ for a gain of $2.6 \mathrm{~mm}$. The range was $2.0 \mathrm{~mm}$ to $4.0 \mathrm{~mm}$. 
Finally Keith (2004) published a case report on ridge augmentation with a Biomend membrane and a cortico cancellous (Puros J-block) block allograft. The initial ridge width was $3 \mathrm{~mm}$ and increased to $9 \mathrm{~mm}$ at 4 month reentry. This corresponds to a 6 mm gain in ridge width.

Table 8

Barrier Membrane with Allograft Horizontal Augmentation

\begin{tabular}{|l|c|c|c|c|c|c|}
\hline Author & $\begin{array}{c}\# \\
\text { Cases }\end{array}$ & $\begin{array}{c}\text { Initial } \\
(\mathrm{mm})\end{array}$ & $\begin{array}{c}\text { Final } \\
(\mathrm{mm})\end{array}$ & $\begin{array}{c}\text { Change } \\
(\mathrm{mm})\end{array}$ & $\begin{array}{c}\text { Range } \\
(\mathrm{mm})\end{array}$ & Histology \\
\hline $\begin{array}{l}\text { Feuille et al. } \\
2003\end{array}$ & 10 & 4.3 & 7.4 & 3.2 & $1.5-5.0$ & Yes \\
\hline $\begin{array}{l}\text { Lyford et al. } \\
2003\end{array}$ & 3 & 3.4 & 6.0 & 2.6 & $2.0-4.0$ & No \\
\hline $\begin{array}{l}\text { Keith } \\
2004\end{array}$ & 1 & 3.0 & 9.0 & 6.0 & NA & No \\
\hline Mean & 14 & & & 3.9 & & \\
\hline
\end{tabular}

Table 9

Barrier Membrane with Allograft Vertical Augmentation

\begin{tabular}{|l|c|c|c|c|c|c|}
\hline Author & $\begin{array}{c}\# \\
\text { Cases }\end{array}$ & $\begin{array}{c}\text { Initial } \\
(\mathrm{mm})\end{array}$ & $\begin{array}{c}\text { Final } \\
(\mathrm{mm})\end{array}$ & $\begin{array}{c}\text { Change } \\
(\mathrm{mm})\end{array}$ & $\begin{array}{c}\text { Range } \\
(\mathrm{mm})\end{array}$ & Histology \\
\hline $\begin{array}{l}\text { Feuille et al. } \\
2003\end{array}$ & 10 & 8.2 & 7.8 & 0.4 & $-4.0-2.0$ & Yes \\
\hline $\begin{array}{l}\text { Kaufman et } \\
\text { al. 2003 }\end{array}$ & 1 & NA & NA & 4.5 & $4.0-5.0$ & No \\
\hline Mean & 11 & & & 2.5 & & \\
\hline
\end{tabular}




\section{Graft Comparisons}

One animal study compared several different types of grafts placed under titanium reinforced membranes (Buser et al. 1998). Bony defects were created in pig mandibles and then grafted them with either autogenous bone chips, tricalcium phosphate, hydroxylapatite, collagen sponge, or DFDBA 250-500 micrometers. The grafts were allowed to heal for a period of 6 months and then evaluated histologically. The results are presented in table 5. All of the grafting materials produced significant amounts of new bone. HA had the largest percentage of filler material still present.

\section{Table 10}

\section{Histomorphometric Summary Analysis I}

\begin{tabular}{|l|c|c|c|}
\hline Filler & \% Vital Bone & $\begin{array}{c}\text { \%Marrow } \\
\text { Space }\end{array}$ & $\begin{array}{c}\text { \%onvital } \\
\text { Bone }\end{array}$ \\
\hline Blood clot & 55.3 & 44.8 & 0 \\
\hline Collagen & 50.7 & 49.3 & 0 \\
\hline Autograft & 53.6 & 35.3 & 11.0 \\
\hline DFDBA & 43.6 & 43.1 & 13.3 \\
\hline TCP & 69.7 & 24.6 & 5.8 \\
\hline HA & 49.0 & 20.5 & 30.6 \\
\hline
\end{tabular}

Jovanovic and Nevins (1995) reported three GBR cases in humans. A titanium membrane alone was compared to a membrane plus an autograft, and to a membrane plus an allograft. The membrane alone site was $2 \mathrm{~mm}$ in width initially. At 12 month reentry the width was $7 \mathrm{~mm}$ for an increase of $5 \mathrm{~mm}$. In the membrane plus autograft the initial ridge width was again $2 \mathrm{~mm}$. At the two month reentry the ridge width was $8 \mathrm{~mm}$ for a gain of $6 \mathrm{~mm}$. Finally, in the membrane plus allograft group the initial ridge width was 3 
$\mathrm{mm}$ and it increased to $9 \mathrm{~mm}$ at 7 month reentry for a gain of $6 \mathrm{~mm}$ of ridge width. Based on this study and the previous one by Buser et al. (1998) there does not seem to be much difference in the quantity and quality of bone regenerated as long as sound guided bone regeneration technique is used. This can be seen in the following table that summarizes width increases in GBR studies.

\section{Table 11}

\section{Jovanovic and Nevins (1995)}

\begin{tabular}{|c|c|c|c|c|}
\hline & $\begin{array}{c}\text { Initial Ridge } \\
\text { width }\end{array}$ & $\begin{array}{c}\text { Final Ridge } \\
\text { Width }\end{array}$ & $\begin{array}{c}\text { Ridge Width } \\
\text { Gain }\end{array}$ & Reentry Time \\
\hline $\begin{array}{c}\text { Membrane } \\
\text { Alone }\end{array}$ & $2 \mathrm{~mm}$ & $7 \mathrm{~mm}$ & $5 \mathrm{~mm}$ & 12 months \\
\hline $\begin{array}{c}\text { Membrane and } \\
\text { Autograft }\end{array}$ & $2 \mathrm{~mm}$ & $8 \mathrm{~mm}$ & $6 \mathrm{~mm}$ & 2 months \\
\hline $\begin{array}{c}\text { Membrane and } \\
\text { Allograft }\end{array}$ & $3 \mathrm{~mm}$ & $9 \mathrm{~mm}$ & $6 \mathrm{~mm}$ & 7 months \\
\hline
\end{tabular}


Table 12

GBR Horizontal Augmentation Summary

\begin{tabular}{|l|c|c|c|}
\hline Treatment Type & \# Studies & \# Cases & $\begin{array}{c}\text { Width Increase } \\
(\mathrm{mm})\end{array}$ \\
\hline Barrier Membrane Alone & 1 & 7 & 2.5 \\
\hline Barrier Membrane with Allograft & 3 & 14 & 3.9 \\
\hline Barrier Membrane with Alloplast & 3 & 37 & 2.0 \\
\hline Barrier Membrane with Autograft & 3 & 43 & 3.9 \\
\hline Barrier Membrane with Various Grafts & 2 & 14 & 3.2 \\
\hline $\begin{array}{l}\text { Comparative Allograft and Autograft } \\
\text { Studies }\end{array}$ & 1 & 3 & 5.7 \\
\hline Comparative Autograft Studies & 2 & 20 & 3.2 \\
\hline Grand Total/Mean & 15 & 138 & 3.5 \\
\hline
\end{tabular}




\section{CHAPTER II}

\section{METHODS}

Study Design. Twenty-four patients were invited to participate in this randomized, controlled, blinded clinical trial for ridge augmentation by guided bone regeneration treatment with an acellular dermal matrix allograft (Alloderm, Biohorizons,

Inc., Birmingham, AL.) as a barrier membrane. Patients were randomly placed into either the positive control or test group based on the result of a coin toss. The positive control group was treated with a cancellous block allograft, and the test group was treated with freeze dried bone allograft particles (500-1000 microns in diameter).

After four months of healing all sites were reentered and an implant was placed. Whenever possible a biopsy core was taken from the implant site for histologic analysis. 
Figure I

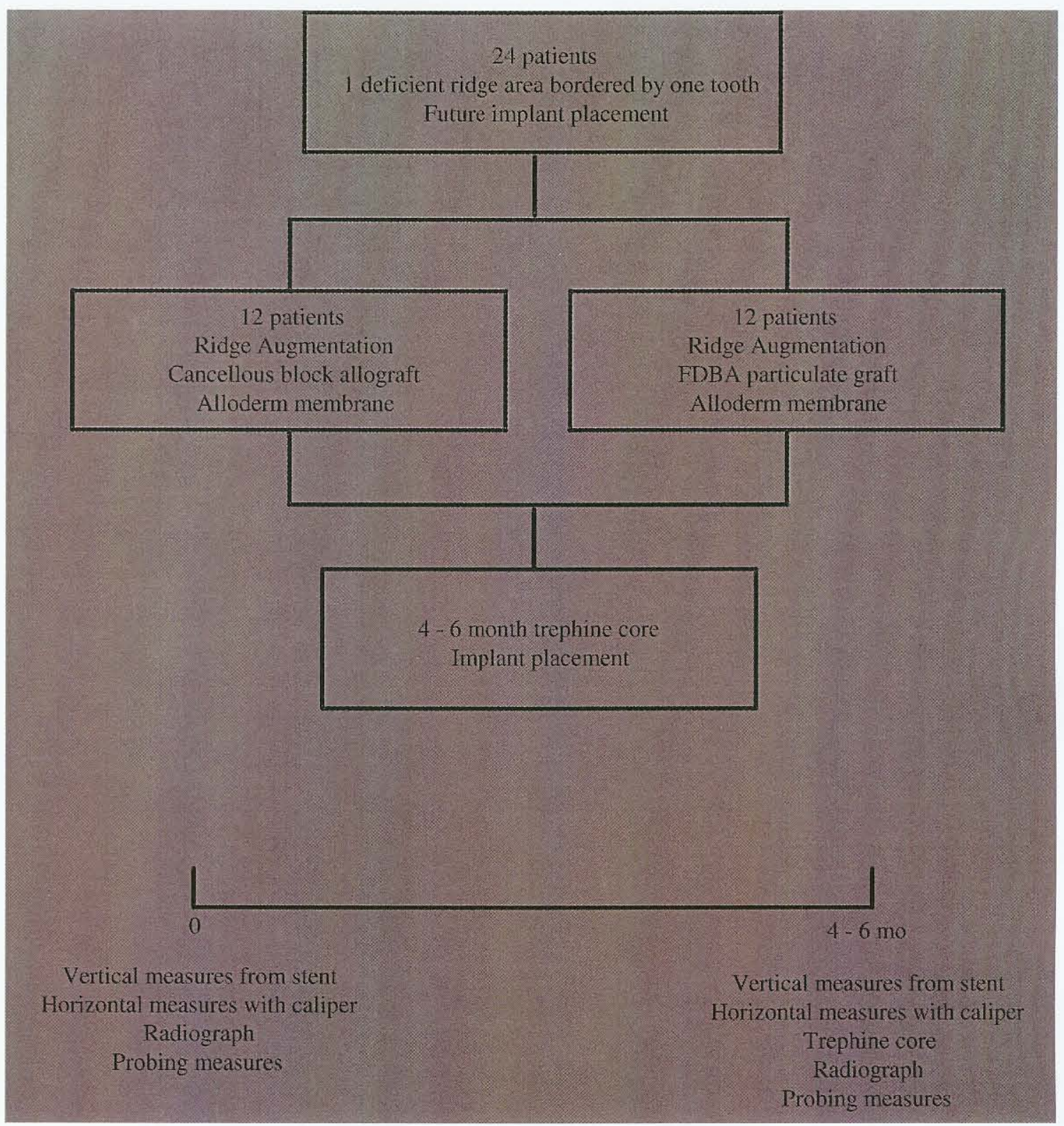

\section{Patient Selection}

\section{Inclusion Criteria}

1. The patient must have at least a one tooth area with a ridge defect, treatment planned to receive a dental implant. The site must be bordered by at least one tooth. 
2. The patients must be at least 18 years old.

3. Patients must sign an informed consent to clinical research previously approved by the University of Louisville Human Studies Committee.

\section{Exclusion Criteria}

1. Patients with uncontrolled diabetes, immune diseases or other contraindicated systemic diseases.

2. Patients with uncontrolled periodontal disease, and unwillingness to undergo needed periodontal treatment or patients with any other diseases that affect the periodontium.

3. Patients with an allergy to any material or medication used in the study.

4. Patients who need prophylactic antibiotics.

5. Previous head and neck radiation therapy.

6. Chemotherapy in the previous 12 months.

7. Severe psychological problems.

\section{Post-Surgical Exclusion}

1. Patients that fail to follow the post-operative protocol will be reported but will not be included in the data analysis.

2. Patients with fixation screw loss will be reported but will not be included in the data analysis. 


\section{Presurgical Management}

Each patient received a diagnostic work-up including standardized radiographs (periapicals), study models, clinical photographs, and a clinical examination of teeth adjacent to the augmented sites. An acrylic stent was fabricated from which intraoperative vertical and horizontal hard tissue measurements were taken.

Baseline data was collected just before the surgical phase of the treatment.

Baseline data included:

1. Plaque Index: Silness and Loe 1964. (Appendix A).

2. Gingival Index: Loe et al. 1967 . (Appendix B).

3. Bleeding on Probing: Dichotomous.

4. Clinical Tooth Mobility: measurement by using the modified Miller's Index. (Appendix C).

5. Gingival Margin Levels: measurement from CEJ to the gingival margin.

6. Keratinized Gingiva Width: measured from the gingival margin to the mucogingival junction.

7. Clinical Attachment Level: measurement from CEJ to the bottom of the clinical periodontal pocket.

8. Radiographic Examination: Periapical radiograph on personalized Rinn XCP. (Appendix D).

9. Soft Tissue Thickness: SDM gingival thickness meter. (Appendix H).

10. Clinical photographs. 
Soft tissue thickness and hard tissue measurements were done by two blinded examiners. Any measurements that differed by more than $1.0 \mathrm{~mm}$ were repeated until the difference between the two examiners was less than $1.0 \mathrm{~mm}$.

Surgical treatment. Patients were anesthetized with $2 \%$ lidocaine with epinephrine 1:100,000. Horizontal crestal incisions were made midcrestally on the mandibular sites with care taken to preserve keratinized tissue on both sides of the incision. In maxillary sites the horizontal incision was made $10-15 \mathrm{~mm}$ palatal to the palatal line angles of the adjacent teeth. Long vertical incisions were made on the buccal from the mesial and distal extents of the horizontal incision. The vertical incisions were designed to diverge as much as possible. A superficial split thickness flap (Greenwell et al. 2004) was reflected on the buccal, and a full thickness flap was reflected on the lingual. Periosteum and muscle layers were reflected on the buccal to expose the ridge defect.

Ridge width was measured at the crest and $5 \mathrm{~mm}$ apical to the crest by both examiners using a digital caliper. Vertical hard tissue measurements were taken using the custom made acrylic stent (Appendix F).

The coin toss was performed at this time to determine the patient's treatment assignment. The positive control group had a cancellous block allograft (Allosource, Inc., Centennial, CO.) shaped using carbide burs under copious irrigation. The block was shaped to closely adapt to the alveolar ridge without any sharp edges. Numerous cortical perforations were made at the recipient site with a $1 / 2$ or 2 round bur. The block graft was secured to the recipient with either one or two titanium screws (Salvin Dental Specialties, Inc., Charlotte, NC). Any voids left by the block graft were filled with freeze 
dried bone allograft particles (500-1000 microns), and the block graft was overlayed by particulate graft as well. The graft was covered by an Alloderm barrier membrane that extended at least $3 \mathrm{~mm}$ beyond the graft border in all directions.

The test sites were prepared with cortical perforations in the same manner as the positive control sites. Two or more titanium screws were placed in the recipient site. The screws were left protruding from the alveolar ridge so that they defined the desired post-graft ridge dimensions. The Alloderm barrier membrane was secured apically on the buccal with two or three titanium tacks. Freeze dried bone allograft particles (5001000 microns) were packed into the recipient site to the dimensions set by the screws. The Alloderm membrane was then pulled over the graft and tucked on the lingual or palatal aspect. Post graft ridge width and vertical stent measurements were then performed by both examiners.

Primary closure was then obtained in all cases using a resorbable monofilament (Maxon 5.0) suture. One to three deep horizontal mattress sutures were placed $10 \mathrm{~mm}$ apical to the horizontal wound margins to remove tension from the wound margins. The horizontal and vertical wound margins were then closed with numerous interrupted and horizontal mattress sutures. All procedures were documented with clinical photographs. Patients were given doxycycline $50 \mathrm{mg}, 1$ tab qd, for 2 weeks; naproxen $375 \mathrm{mg}, 1$ tab bid, for 1 week, Vicodin ES, 1 tab q 4-6 h, as needed for pain, and chlorehexidine $0.12 \%$, bid rinse, for 3 weeks. All patients were seen on a weekly basis until soft tissue closure was obtained. Post-op visits included supragingival plaque removal and oral hygiene reinforcement. Sutures were removed at the 3 week post-op appointment. 
All sites were reentered at least 4 months after the ridge augmentation surgery. Clinical measurements were repeated as performed prior to the initial surgery. Patients were anesthetized with $2 \%$ lidocaine with epinephrine 1:100,000. A superficial split thickness flap was reflected on the buccal so primary closure could be assured if additional grafting were needed. A $2.7 \times 6 \mathrm{~mm}$ biopsy core was taken from the implant site. Ridge width and vertical measurements were repeated by both examiners. Implants were placed and any dehiscence sites were grafted with freeze dried bone allograft particles (500-1000 microns). Flaps were replaced and sutured with 4.0 chromic gut sutures. Patients were given the same post operative medications as those prescribed after the initial surgery.

Histologic Analysis. Trephine core specimens $(2.7$ X $6 \mathrm{~mm})$ were decalcified, sectioned, and prepared for histologic analysis using hematoxylin and eosin staining. 12 to 15 step serial sections were taken from the center of each longitudinally sectioned trephine core. Six randomly selected fields, 1 per slide if possible, were used to obtain percent cellular bone, acellular bone, and trabecular space using an American Optics light microscope at $150 \mathrm{X}$, with a $10 \mathrm{X}$ objective and Nikon $15 \mathrm{X}$ reticle eyepiece, Appendix $\mathrm{H}$.

Statistical Analysis. A 2-way ANOVA was used to evaluate the statistical significance of the differences between groups and changes from baseline to final examination. 


\section{CHAPTER III}

\section{RESULTS}

Alveolar Ridge Width Changes at Crest. The block or positive control group had an initial ridge width of $3.3 \pm 0.9 \mathrm{~mm}$ at the crest. At reentry the ridge width was 7.1 $\pm 1.0 \mathrm{~mm}$ for an increase of $3.8 \pm 1.3 \mathrm{~mm}$ (Table 13). This increase was statistically significant $(\mathrm{p}<0.05)$. The particulate or test group had an initial ridge width at the crest of $4.4 \pm 1.0$. At reentry the width was $7.7 \pm 1.5 \mathrm{~mm}$ for an increase of $3.3 \pm 1.1 \mathrm{~mm}$. That increase was statistically significant $(\mathrm{p}<0.05)$. There was no statistically significant difference between groups $(\mathrm{p}>0.05)$

Predictability of Ridge Width at Reentry. For a standard diameter implant to be placed completely in bone it is necessary to have a ridge width of $6 \mathrm{~mm}$ or greater. In the block and particulate groups that was the case group $83 \%$ of the time. (Table 13). For a wide diameter implant to be placed entirely in bone a ridge width of $7 \mathrm{~mm}$ or greater is necessary. This was the case in $50 \%$ of the block cases and $75 \%$ of the particulate cases (Table 13). A ridge width of less than $4 \mathrm{~mm}$ might preclude implant placement entirely. None of the reentry ridge widths in either the block or particulate groups were $4 \mathrm{~mm}$ or less (Table 13).

Alveolar Ridge Width $5 \mathbf{~ m m}$ Apical to the Crest. The block group had an initial ridge width of $5.6 \pm 1.1 \mathrm{~mm}$ at $5 \mathrm{~mm}$ apical to the crest. At reentry the ridge width 
was $9.0 \pm 1.2 \mathrm{~mm}$ for an increase of $3.4 \pm 1.0 \mathrm{~mm}$ (Table 14). The particulate group had an initial ridge width of $6.9 \pm 1.1 \mathrm{~mm} 5 \mathrm{~mm}$ apical to the crest. At reentry the ridge width was $9.7 \pm 1.7 \mathrm{~mm}$ for an increase of $2.9 \pm 1.0 \mathrm{~mm}$. Both groups had statistically significant increases within the groups $(\mathrm{p}<0.05)$. There was no difference between the groups $(\mathrm{p}>0.05)$.

Loss of Augmented Ridge Width at the Crest. The initial augmented ridge width for the block group was $8.7 \pm 1.0$ (Table 15). At reentry the ridge width was $7.1 \pm$ $1.0 \mathrm{~mm}$ for a loss of $1.6 \pm 1.0 \mathrm{~mm}$ of augmented ridge width $(18 \pm 11 \%)$. The initial augmented ridge width for the particulate group was $9.0 \pm 0.9 \mathrm{~mm}$. At reentry the ridge width was $7.7 \pm 1.5 \mathrm{~mm}$ for a loss of $1.4 \pm 1.4 \mathrm{~mm}(15 \pm 15 \%)$ of augmented width. Both of the groups had statistically significant changes within the groups, but there was no significant difference between the groups $(\mathrm{p}>0.05)$.

Alveolar Ridge Height Changes. Ridge height changes for the mid sites in the block group was a gain of $0.7 \pm 1.0 \mathrm{~mm}$ (Table 16). This was a statistically significant increase $(\mathrm{p}<0.05)$. Ridge height change for the mid sites in the particulate group was a gain of $0.3 \pm 0.6 \mathrm{~mm}$. This was not a statistically significant change $(p>0.05)$. The mean mesial ridge height change for the block group was $0.3 \pm 0.8 \mathrm{~mm}$ and for the particulate group was $0.1 \pm 0.7 \mathrm{~mm}$. The mean distal ridge height change for the block group was $0.2 \pm 1.1$ and for the particulate group was $0.4 \pm 1.1 \mathrm{~mm}$. None of the mesial or distal changes were statistically significant $(\mathrm{p}>0.05)$. There was no statistically significant difference between the groups $(\mathrm{p}>0.05)$ (Table 16).

Histologic Evaluation. The percentage of vital bone at the implant site in the block group was $51 \pm 18 \%$ (Table 17). The percentage of vital bone at the implant site 
for the particulate group was $58 \pm 12 \%$. The percentage of non-vital bone in the block group was $11 \pm 9 \%$. The percentage of non-vital bone in the particulate group was $11 \pm$ $7 \%$.

Predictability of Planned Implant Placement. In the block group implants were placed as planned in 12 of 12 sites or $100 \%$ of the time (Table 18). In the particulate group implants were placed as planned or a larger diameter in 12 of 12 sites or $100 \%$ of the time.

Soft Tissue Thickness Changes. In the block group the occlusal sites had a mean increase of $0.8 \pm 0.7 \mathrm{~mm}$ of soft tissue thickness (Table 19). The increase was statistically significant $(p<0.05)$. The buccal sites had a mean increase of $0.3 \pm 0.7 \mathrm{~mm}$, and the lingual sites had a mean increase of $0.4 \pm 0.6 \mathrm{~mm}$. Neither the buccal nor lingual changes were statistically significant. In the particulate group the mean increase of soft tissue thickness was $0.6 \pm 1.0 \mathrm{~mm}$ on the buccal and $0.3 \pm 0.7 \mathrm{~mm}$ on the occlusal. Neither of these changes was statistically significant. The soft tissue thickness increased $0.3 \pm 0.4 \mathrm{~mm}$ on the lingual sites. This was a statistically significant increase $(\mathrm{p}<0.05)$. There was no statistically significant difference between the groups $(p>0.05)$.

Clinical Indices. The plaque index, gingival index, and bleeding on probing values for the test and positive control groups were initially very low with minimal differences between groups (Table 20). There was no statistically significant difference between groups $(p>0.05)$. At reentry the values had increased slightly with no clinical or statistical significance between groups from intial to final ( $p>0.05)$. 
Table 13

Ridge Width Changes at the Crest for Block and Particulate Allograft Sites

\begin{tabular}{|c|c|c|c|}
\hline Treatment & Initial & Final & Change \\
\hline \multicolumn{4}{|c|}{ Mean \pm sd } \\
\hline Block & $3.3 \pm 0.9$ & $7.1 \pm 1.0$ & $3.8 \pm 1.3^{*}$ \\
\hline Particulate & $4.4 \pm 1.0$ & $7.7 \pm 1.5$ & $3.3 \pm 1.1^{*}$ \\
\hline \multicolumn{4}{|c|}{ Range } \\
\hline Block & $2.0-4.5$ & $5.6-9.0$ & $1.8-5.8$ \\
\hline Particulate & $3.0-5.9$ & $5.2-10.6$ & $1.6-4.7$ \\
\hline \multicolumn{4}{|c|}{ Frequency } \\
\hline & $\geq 6 \mathrm{~mm}$ & $\geq 7 \mathrm{~mm}$ & $\leq 4 \mathrm{~mm}$ \\
\hline Block (number) & $10 / 12$ & $6 / 12$ & $0 / 12$ \\
\hline Block (percent) & 83 & 50 & 0 \\
\hline Particulate (number) & $10 / 12$ & $9 / 12$ & $0 / 12$ \\
\hline Particulate (percent) & 83 & 75 & 0 \\
\hline
\end{tabular}

$*=p<0.05$ between initial and 4 -month values 
Table 14

Ridge Width Changes $5 \mathrm{~mm}$ apical to the Crest for Block and Particulate Allograft Sites

\begin{tabular}{|c|c|c|c|}
\hline Treatment & Initial & Final & Change \\
\hline \multicolumn{4}{|c|}{ Mean \pm sd } \\
\hline Block & $5.6 \pm 1.1$ & $9.0 \pm 1.2$ & $3.4 \pm 1.0^{*}$ \\
\hline Particulate & $6.9 \pm 1.1$ & $9.7 \pm 1.7$ & $2.9 \pm 1.0^{*}$ \\
\hline \multicolumn{4}{|c|}{ Range } \\
\hline Block & $4.4-7.7$ & $7.4-11.0$ & $1.7-5.2$ \\
\hline Particulate & $5.1-8.4$ & $6.9-12.5$ & $1.3-4.5$ \\
\hline
\end{tabular}

$*=p<0.05$ between initial and 4 -month values 


\section{Table 15}

Loss of Augmented Ridge Width at the Crest for Block and Particulate Allograft Sites

\begin{tabular}{|lccc|}
\hline Treatment & Augmented Width & Re-entry & Change \\
\hline \multicolumn{2}{c|}{ Mean \pm sd } \\
\hline Block & $8.7 \pm 1.0$ & $7.1 \pm 1.0$ & $-1.6 \pm 1.0^{*}$ \\
Block percent loss & & $18 \pm 11$ \\
Particulate & $9.0 \pm 0.9$ & $7.7 \pm 1.5$ & $-1.4 \pm 1.4^{*}$ \\
Particulate \% loss & & $15 \pm 15$ \\
\hline
\end{tabular}

$*=p<0.05$ between initial and 4 -month values 
Table 16

Ridge Height Changes Relative to a Stent for Block and Particulate Sites

\begin{tabular}{|lcccc|}
\hline Location & Block & Particulate & Block & Particulate \\
\hline \multicolumn{2}{c}{ Mean $\pm \mathrm{sd}$} & \multicolumn{2}{c|}{ Range } \\
\hline Mesial & $0.3 \pm 0.8$ & $0.1 \pm 0.7$ & $-0.5-1.8$ & $-0.8-1.5$ \\
Mid & $0.7 \pm 1.0^{*}$ & $0.3 \pm 0.6$ & $-0.5-2.2$ & $-0.5-1.5$ \\
Distal & $0.2 \pm 1.1$ & $0.4 \pm 1.1$ & $-1.0-2.5$ & $-0.8-3.3$ \\
\hline
\end{tabular}

$*=p<0.05$ between initial and 4 -month values 
Table 17

Histologic Data for Block and Particulate groups

Mean $\pm \mathrm{sd}$

\begin{tabular}{|c|c|c|c|c|c|c|}
\hline Group & Time & $\mathbf{n}$ & $\begin{array}{c}\% \\
\text { Vital }\end{array}$ & $\begin{array}{c}\% \\
\text { Non-vital }\end{array}$ & $\begin{array}{c}\% \\
\text { Trabecular }\end{array}$ & $\begin{array}{c}\% \\
\text { Amorphous }\end{array}$ \\
\hline \multicolumn{7}{|c|}{ Treatment Groups } \\
\hline Block & 4 mo & 11 & $51 \pm 18$ & $11 \pm 9$ & $31 \pm 17 *$ & $7 \pm 6^{*}$ \\
\hline Particulate & $4 \mathrm{mo}$ & 10 & $58 \pm 12$ & $11 \pm 7$ & $17 \pm 8$ & $14 \pm 6$ \\
\hline \multicolumn{7}{|c|}{ Age } \\
\hline$\geq \mathbf{5 0}$ & $4 \mathrm{mo}$ & 12 & $52 \pm 16$ & $12 \pm 6$ & $25 \pm 16$ & $11 \pm 7$ \\
\hline$<50$ & 4 mo & 9 & $56 \pm 16$ & $10 \pm 9$ & $25 \pm 15$ & $9 \pm 6$ \\
\hline \multicolumn{7}{|c|}{ Bone Quality } \\
\hline Type II & $4 \mathrm{mo}$ & 14 & $57 \pm 16$ & $12 \pm 9$ & $19 \pm 11$ & $12 \pm 6$ \\
\hline Type III & 4 mo & 7 & $48 \pm 15$ & $9 \pm 5$ & $37 \pm 16$ & $7 \pm 6$ \\
\hline \multicolumn{7}{|c|}{ Tooth Type } \\
\hline Anteriors & $4 \mathrm{mo}$ & 3 & $52 \pm 6$ & $5 \pm 4$ & $38 \pm 3$ & $5 \pm 4$ \\
\hline Premolars & $4 \mathrm{mo}$ & 8 & $50 \pm 18$ & $13 \pm 8$ & $26 \pm 18$ & $11 \pm 7$ \\
\hline Molars & 4 mo & 10 & $58 \pm 17$ & $11 \pm 8$ & $19 \pm 13$ & $12 \pm 7$ \\
\hline
\end{tabular}

$*=p<0.05$ between block and particulate groups 
Table 18

Predictability of Planned Implant Placement Entirely within Hard Tissue

\begin{tabular}{|c|c|c|c|c|}
\hline & Sites & $\begin{array}{l}\text { Planned } \\
\text { Size }\end{array}$ & $\begin{array}{c}\text { Placed Planned } \\
\text { Size } \\
\end{array}$ & $\begin{array}{c}\text { Placed Smaller } \\
\text { Size } \\
\end{array}$ \\
\hline \multicolumn{5}{|l|}{ Block } \\
\hline Reduced & 7,10 & 2 & 2 & 0 \\
\hline Regular & $6,20,20,20,21,28,29$ & 7 & 7 & 0 \\
\hline Wide & $19,19,19$ & 3 & 3 & 0 \\
\hline $\begin{array}{l}\text { Planned } \\
\text { Placement }\end{array}$ & \multicolumn{4}{|c|}{ Placed as planned in 12 of 12 sites or $100 \%$ of the time } \\
\hline Total Placement & $100 \%$ & & & \\
\hline \multicolumn{5}{|l|}{ Particulate } \\
\hline Reduced & & 0 & 0 & 0 \\
\hline Regular & $4,5,20,29$ & 5 & 4 & 0 \\
\hline Wide & $19,19,19,19,29,30,30,30$ & 7 & 8 & 0 \\
\hline $\begin{array}{l}\text { Planned } \\
\text { Placement }\end{array}$ & \multicolumn{4}{|c|}{ Placed as planned or larger size in 12 of 12 sites or $100 \%$ of the time } \\
\hline Total Placement & $100 \%$ & & & \\
\hline
\end{tabular}


Table 19

Soft Tissue Thickness Changes for Block and Particulate Sites

Mean $\pm \mathrm{sd}$ in $\mathrm{mm}$

\begin{tabular}{|lccc|}
\hline & Initial & Final & Change \\
\hline Block & & & \\
Buccal & $1.4 \pm 0.6$ & $1.7 \pm 0.6$ & $0.3 \pm 0.7$ \\
Occlusal & $1.8 \pm 1.1$ & $2.6 \pm 0.9$ & $0.8 \pm 0.7^{*}$ \\
Lingual & $1.4 \pm 1.3$ & $1.8 \pm 1.3$ & $0.4 \pm 0.6$ \\
\hline Particulate & & & \\
Buccal & $1.3 \pm 0.6$ & $1.9 \pm 0.8$ & $0.6 \pm 1.0$ \\
Occlusal & $1.8 \pm 0.4$ & $2.1 \pm 0.9$ & $0.3 \pm 0.7$ \\
Lingual & $1.0 \pm 0.9$ & $1.3 \pm 0.7$ & $0.3 \pm 0.4^{*}$ \\
\hline
\end{tabular}

$*=p<0.05$ between initial and 4 -month values 


\section{Table 20}

Clinical Indices for Block and Particulate Sites

$$
\text { Mean } \pm \text { sd in index units }
$$

\begin{tabular}{|c|c|c|c|c|}
\hline & & Initial & Final & Change \\
\hline Plaque & Block & $0.3 \pm 0.4$ & $0.4 \pm 0.3$ & $0.1 \pm 0.4$ \\
\hline Index & Particulate & $0.4 \pm 0.5$ & $0.6 \pm 0.7$ & $0.3 \pm 0.6$ \\
\hline Gingival & Block & $0.4 \pm 0.3$ & $0.7 \pm 0.5$ & $0.3 \pm 0.4$ \\
\hline Index & Particulate & $0.4 \pm 0.4$ & $0.5 \pm 0.4$ & $0.2 \pm 0.5$ \\
\hline $\begin{array}{l}\text { Bleeding } \\
\text { on }\end{array}$ & Block & $0.3 \pm 0.3$ & $0.4 \pm 0.3$ & $0.1 \pm 0.3$ \\
\hline Probing & Particulate & $0.3 \pm 0.3$ & $0.5 \pm 0.3$ & $0.1 \pm 0.3$ \\
\hline
\end{tabular}

$*=p<0.05$ between initial and 4-month values 


\section{CHAPTER IV}

\section{DISCUSSION}

In this 4 month randomized, controlled blinded clinical trial a cancellous block allograft (Block) was compared to a mineralized particulate allograft (Particulate) utilizing acellular dermal matrix (ADM) as a barrier membrane. No clinically or statistically significant differences were found between groups in ridge dimension (Tables 13 and 14) change or histologic outcome data (Table 17).

The primary outcome variable was crestal ridge width. The mean final crestal width was $7.1 \pm 1.0 \mathrm{~mm}$ for the Block group and $7.7 \pm 1.5$ for the Particulate group (Table 13). This represented a gain of $3.8 \pm 1.3 \mathrm{~mm}$ for the Block group and $3.3 \pm 1.1$ $\mathrm{mm}$ for the Particulate group (Table 13). Analysis of frequency data showed that both the Block and Particulate groups achieved a crestal width of $\geq 6 \mathrm{~mm} 83 \%$ of the time while a crestal width of $\geq 7 \mathrm{~mm}$ was obtained $50 \%$ of the time in the Block group and $75 \%$ of the time in the Particulate group (Table 13). Crestal width of $\leq 4 \mathrm{~mm}$ did not occur with either treatment (Table 13). A crestal width of $4 \mathrm{~mm}$ was considered inadequate to allow implant placement totally within bone. Final ridge width is dependent, to some extent, on the initial treatment goal which can vary depending on the size of the implant planned for the site. Thus a $4 \mathrm{~mm}$ standard diameter implant would require a minimum crestal ridge width of $6 \mathrm{~mm}$, a $5 \mathrm{~mm}$ wide diameter implant would 
require a $7 \mathrm{~mm}$ width, while a $3.25 \mathrm{~mm}$ reduced diameter implant would require a $5 \mathrm{~mm}$ crestal width.

Predictability of plannned implant placement totally within bone was $100 \%$ for both the Block and the Particulate group. There were 2 reduced, 7 standard and 3 wide implants planned for the Block group and 5 regular and 7 wide for the Particulate group (Table 18). This analysis may best indicate how well each treatment accomplished the goal.

Crestal ridge width is not the only important outcome when adequate ridge dimension to allow implant placement totally within bone is the goal of the ridge augmentation procedure. In many cases the ridge may be severely undercut or concave on the facial, or may simply have a narrow dimension apically. Ridge width changes 5 $\mathrm{mm}$ apical to the crest were taken as a measure of how well the apical portion of the graft site responded. In general the graft extended 10 to $12 \mathrm{~mm}$ apical to the actual or desired crest. The Block group gained $3.4 \pm 1.0 \mathrm{~mm}$ in this area of the graft site while the Particulate group gained $2.9 \pm 1.0 \mathrm{~mm}$. Both of these gains were statistically significant (Table 14). The Particulate group gained about $0.5 \mathrm{~mm}$ less at the crest and at $5 \mathrm{~mm}$ apical to the crest than the Block group, however, the final ridge width was slightly greater for the Particulate group and more wide diameter implants were planned for this group (Tables 13 and 18).

The loss of augmented ridge width was similar for both groups, $18 \%$ for the Block group and $15 \%$ for the Particulate group (Table 15). Previous studies have shown similar losses of 16 and 17\% for a cancellous block allograft (Cordini 2004, Lyford et al. 2003). Some loss of augmented width is expected and the change observed in this study 
was considered minimal. Expected loss associated with a particular graft material is useful to know when the graft is placed so that the augmented dimension can be increased to offset the expected loss. This data may not be generalizable to other block or particulate grafts that could have a different healing pattern.

Ridge height gain measured from a stent was minimal in this study (Table 16). This reflects the type of ridge defect entered into the study. Any patient that met the inclusion criteria was consecutively entered into the study and randomly assigned to a treatment group. Most of the defects encountered were ridge width deficiencies with minimal loss of height. Thus this study did not test how well these materials would respond in vertical defects.

Histologic analysis of data obtained from $2.7 \times 6 \mathrm{~mm}$ trephine cores harvested at the implant placement site showed no significant differences between groups (Table 17). Considering the fact that allografts were used there was high percentage of vital bone and a minimal percentage of nonvital residual graft found at the implant sites. This may be partially due to the fact that the trephine core was taken at the site of implant placement rather than totally within grafted bone. Histology at the implant site was considered most important, however, the composition of the core may not refect graft histology alone but a combination of native and grafted bone. At 3 sites the core broke apart during removal from the trephine and was not available for analysis.

Since there were minimal differences in the histology between groups subsequent analyses were performed without regard to the treatment group. When patients $\geq 50$ years of age were compared to those $<50$ minimal differences were found (Table 17). The mean age of those $\geq 50$ was $64 \pm 7$ while the mean age of the group $<50$ was $40 \pm 8$. 
Site stratification by tooth type also showed minimal histologic differences between anterior, premolar and molar sites although there was slightly more vital bone and less trabecular space in the molar sites (Table 17). In this study 17 of 21 cores were from mandible sites while only 4 were from the maxilla, therefore, this data primarily reflects the histologic outcome in mandibular sites.

Bone quality was subjectively assessed using the criteria of Lekholm \& Zarb (1985). Fourteen sites were considered Type II bone while 7 were assessed as Type III. Histologic analysis of these sites showed $57 \%$ vital bone and $19 \%$ trabecular space at Type II sites while Type III sites had $48 \%$ vital bone and $37 \%$ trabecular space (Table 17). Thus while the bone quaality assessment is subjective the histologic compostion of the sites supports the groupings made in this study.

The acellular dermal matrix used as a barrier membrane also served as a soft tissue graft and increased the soft tissue thickness of the buccal and lingual flaps. Total ridge width, independent of hard tissue changes, was increased by about $0.8 \mathrm{~mm}$ for both groups due to the increase in soft tissue thickness (Table 19). This indicates that ADM may offer an advantage independent of its membrane effect. Previous studies have shown that a loss of soft tissue thickness is associated with the use of resorbable membranes. This can be problematic at certain implant sites since thin tissue can allow the metal implant collar to show through giving the soft tissue and unesthetic, bluish hue.

Ridge width changes in this study were comparable with previous FDBA or cancellous block allograft case series (Feuille et al. 2003; Lyford et al. 2003). This study found about a mean $3.5 \mathrm{~mm}$ gain for both groups while previous reports showed about a $2.9 \mathrm{~mm}$ mean gain (Table 8 ). The mean height gain in this study was about $0.3 \mathrm{~mm}$ 
while previous cases series have reported about 0.4 (Feuille et al. 2003)(Table 9). It should be pointed out that all comparisons are to case series where cases can be selected for treatment. This study was a randomized, controlled, blinded clinical trial that consecutively entered all cases that met the inclusion criteria.

Comparison of data from this study with a previous block autograft case series shows similar results. The mean ridge data from a 40 case series shows a $3.6 \mathrm{~mm}$ width gain. The minimal differences between these studies indicates that the source of the graft material, autogenous or allogeneic, may have minimal influence on the treatment outcome. Wallace and Froum (2003) reported that for sinus grafts there was little difference in implant survival rates when particulate autogenous, allogeneic, xenogeneic and alloplastic materials were compared. Use of graft materials that do not require a second surgical site and avoid donor site morbidity represents a significant advantage for the patient and may increase case acceptance when ridge augmentation is required. Additional randomized, controlled blinded clinical trials are needed to confirm this observation.

In summary, comparison of cancellous block and mineralized particulate allograft showed similar ridge width and height gains. The acellular dermal matrix membrane also served as a soft tissue graft and increased total ridge width by about $0.8 \mathrm{~mm}$. The increased tissue thickness may provide an advantage in preventing unesthetic tissue color due to show through of the metal implant collar. 


\section{CHAPTER V}

\section{CONCLUSIONS}

Mean crestal ridge width gain following ridge augmentation was not significantly different between a cancellous block allograft and a mineralized particulate allograft using acellular dermal matrix as a barrier membrane. (Table 13)

Mean ridge height gain following ridge augmentation was not significantly different between a cancellous block allograft and a mineralized particulate allograft using acellular dermal matrix as a barrier membrane. (Table 16)

The histologic compostion of the implant placement site following ridge augmentation was not significantly different between a cancellous block allograft and a mineralized particulate allograft using acellular dermal matrix as a barrier membrane (Table 17).

Soft tissue thickness was increased following use of acellular dermal matrix as a barrier membrane (Table 19). 
Table 21

Soft Tissue Thickness changes in Ridge Preservation/Augmentation Sites

Mean $\pm \mathrm{sd}$ in $\mathbf{m m}$

\begin{tabular}{|l|l|c|c|c|}
\hline Study/Yr & Tx & B & O & L \\
\hline Iasella 03 & Extr & 0.4 & & 0.5 \\
\hline Vance 04 & Calmatrix & 0.1 & & -0.1 \\
\hline Kirkland 00 & Guidor & -1.1 & -1.5 & -0.8 \\
\hline Iasella 03 & Biomend Ext & -0.1 & & -0.6 \\
\hline Vance 04 & BioGide & -0.2 & & 0.0 \\
\hline Cordini & ADMg-Block & 0.3 & 0.5 & 0.3 \\
\hline Cordini & ADMg-Flex & 0.6 & 0.0 & 0.1 \\
\hline Lahey & ADM-Block & 0.3 & 0.8 & 0.4 \\
\hline Lahey & ADM-Partic & 0.6 & 0.3 & 0.3 \\
\hline Adams & ADM-Intra & 0.9 & & 0.8 \\
\hline Adams & ADM-In-Ov & 0.7 & & 0.8 \\
\hline
\end{tabular}


a)

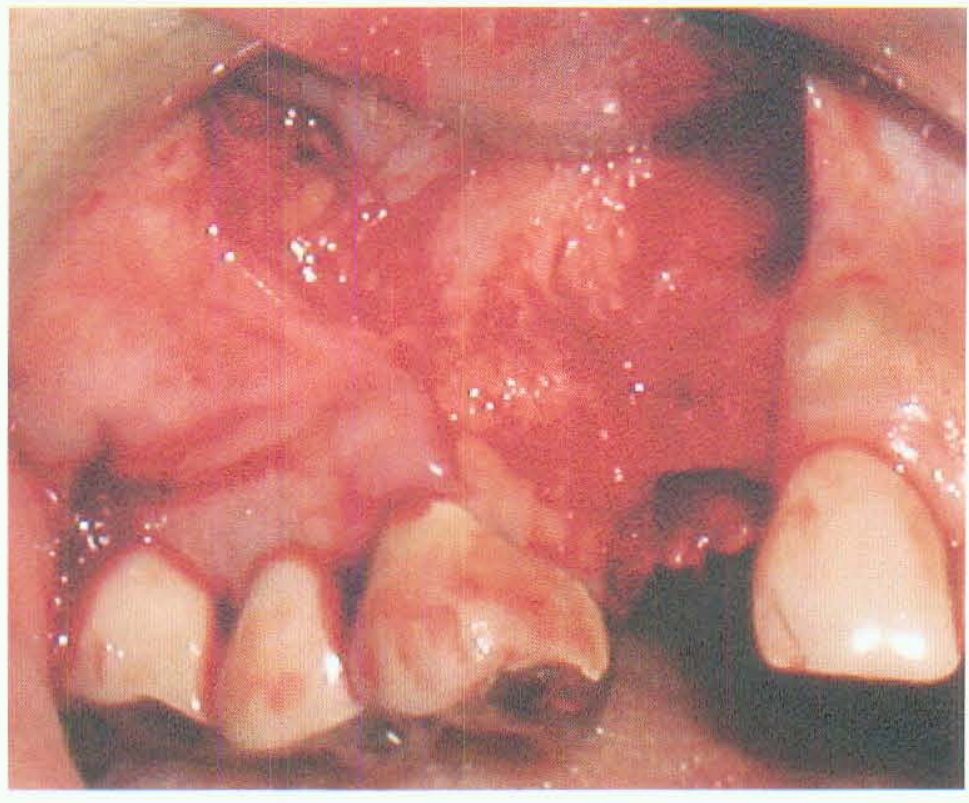

b)

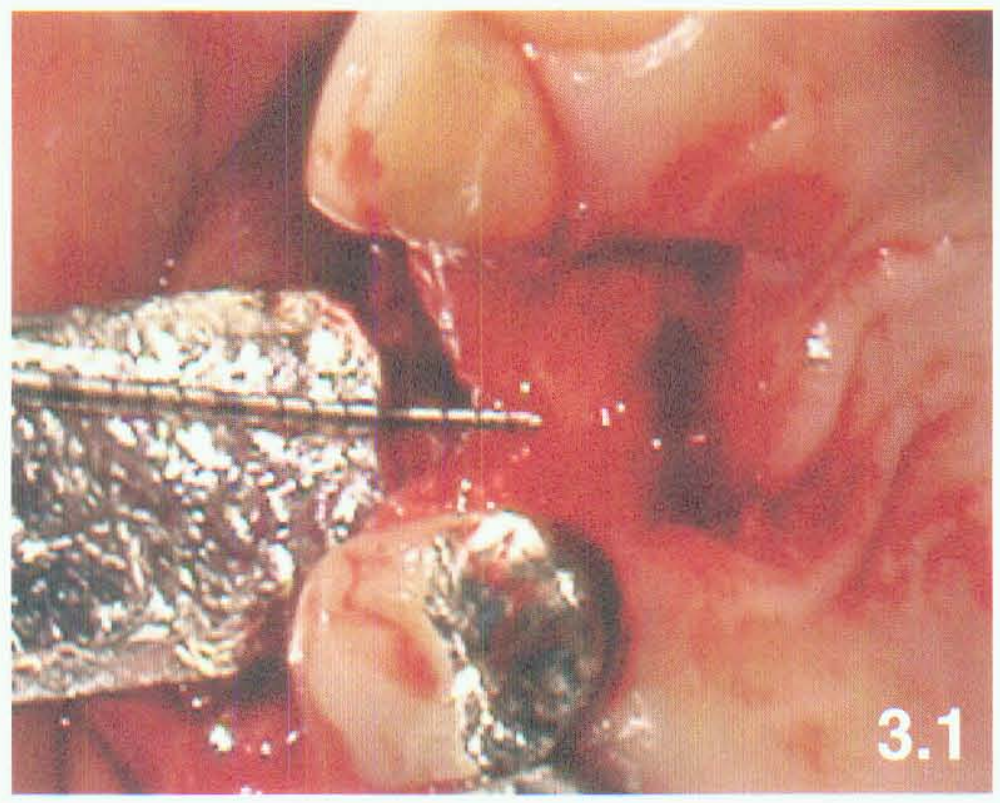

Figure 2. a) Block Pre-Op Facial; b) Block Pre-Op Occlusal 
c)
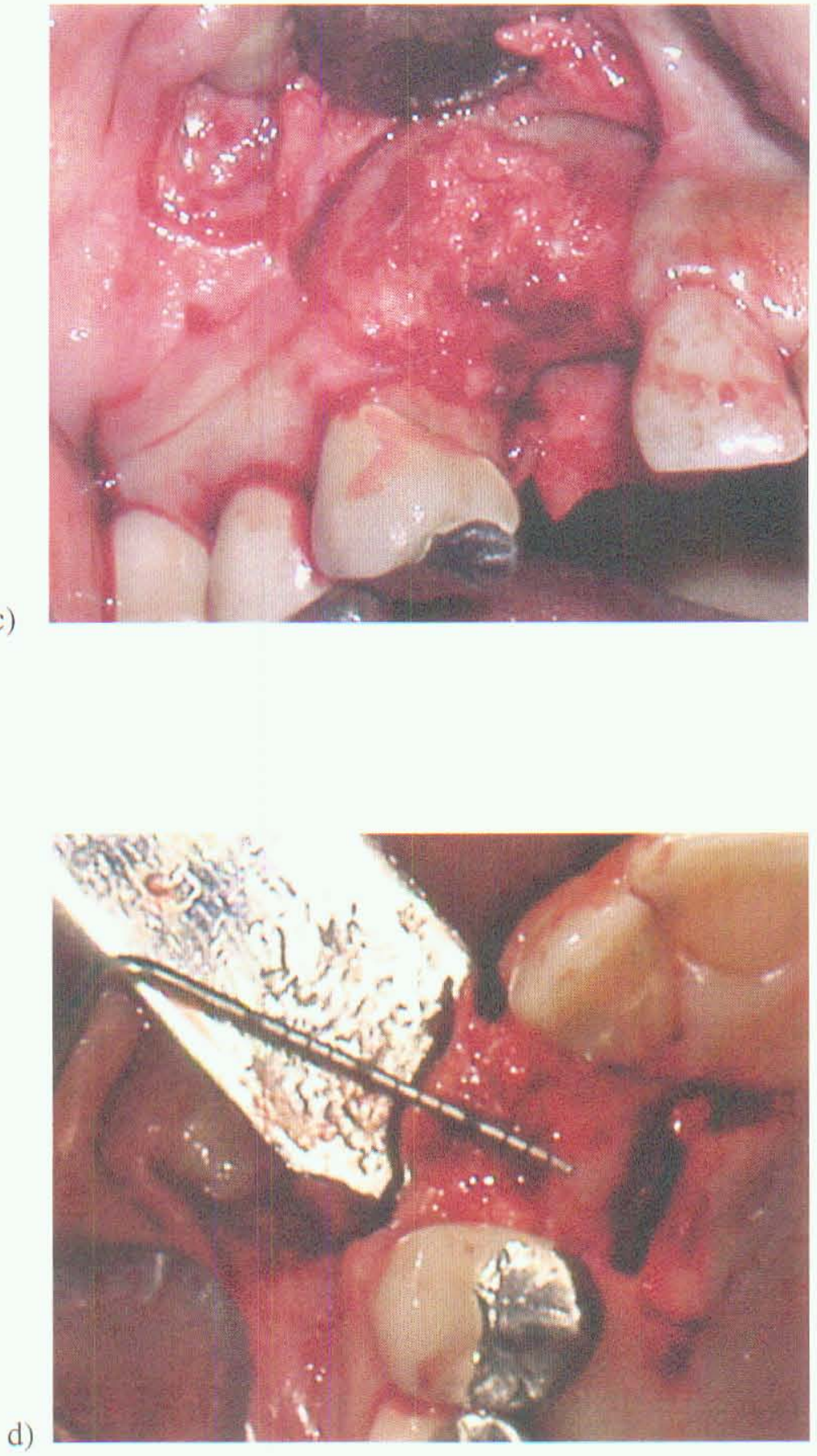

Figure 2. c) Block 4 month reentry facial; d) Block 4 month reentry occlusal 


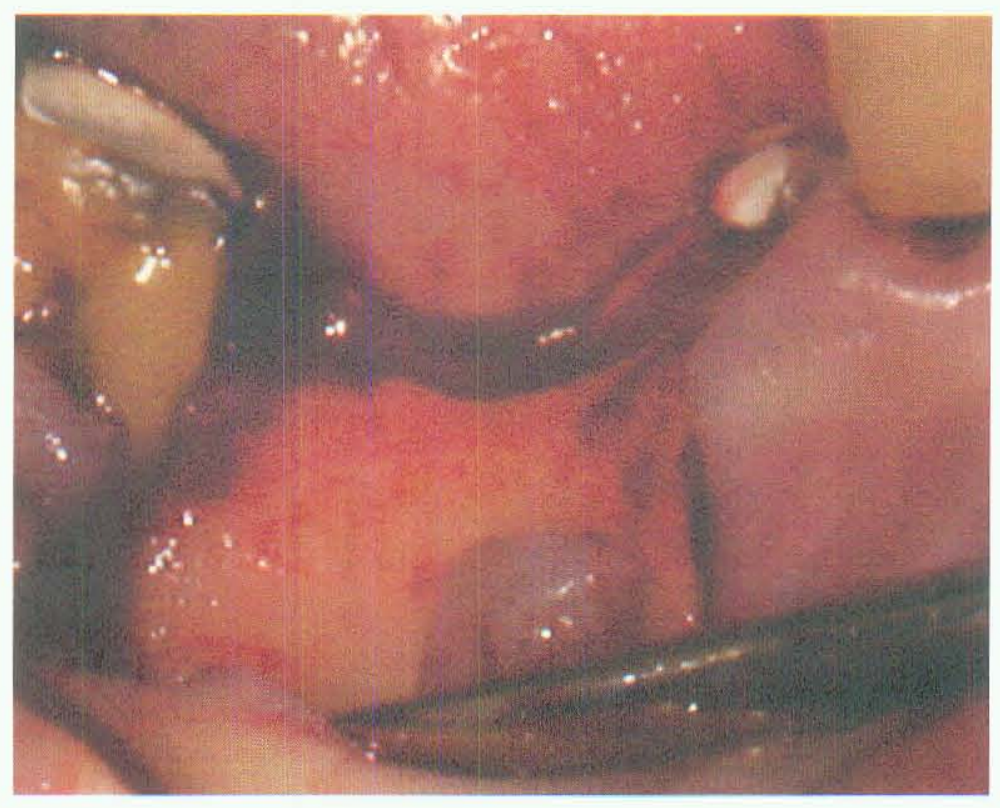

a)

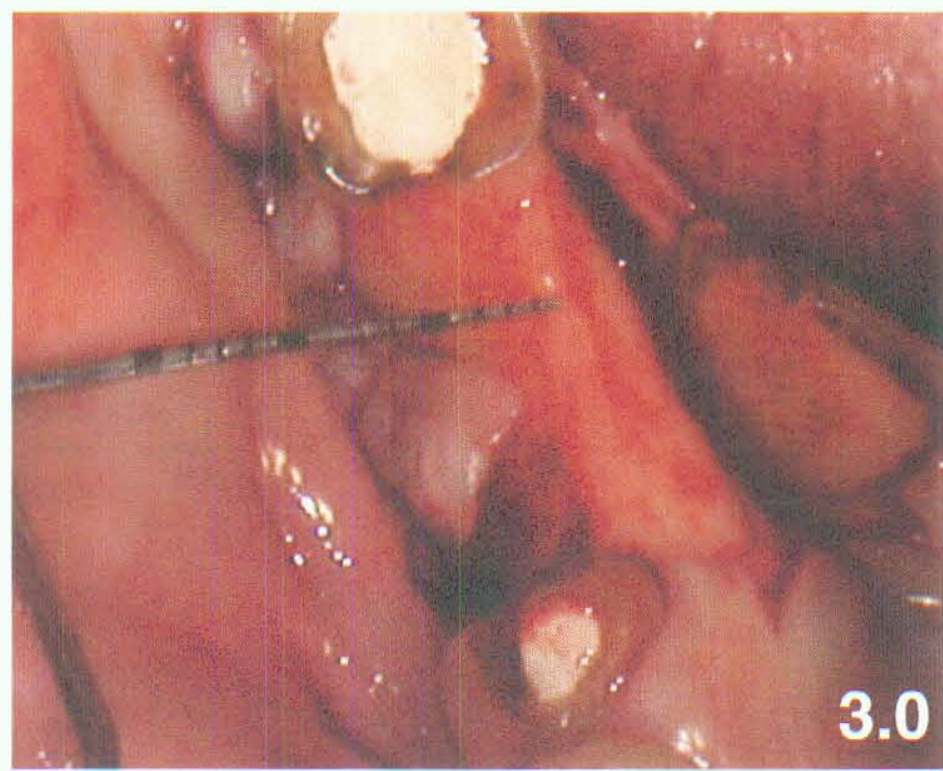

Figure 3. a) Particulate Facial Pre-Op; b) Particulate Occlusal Pre-Op 

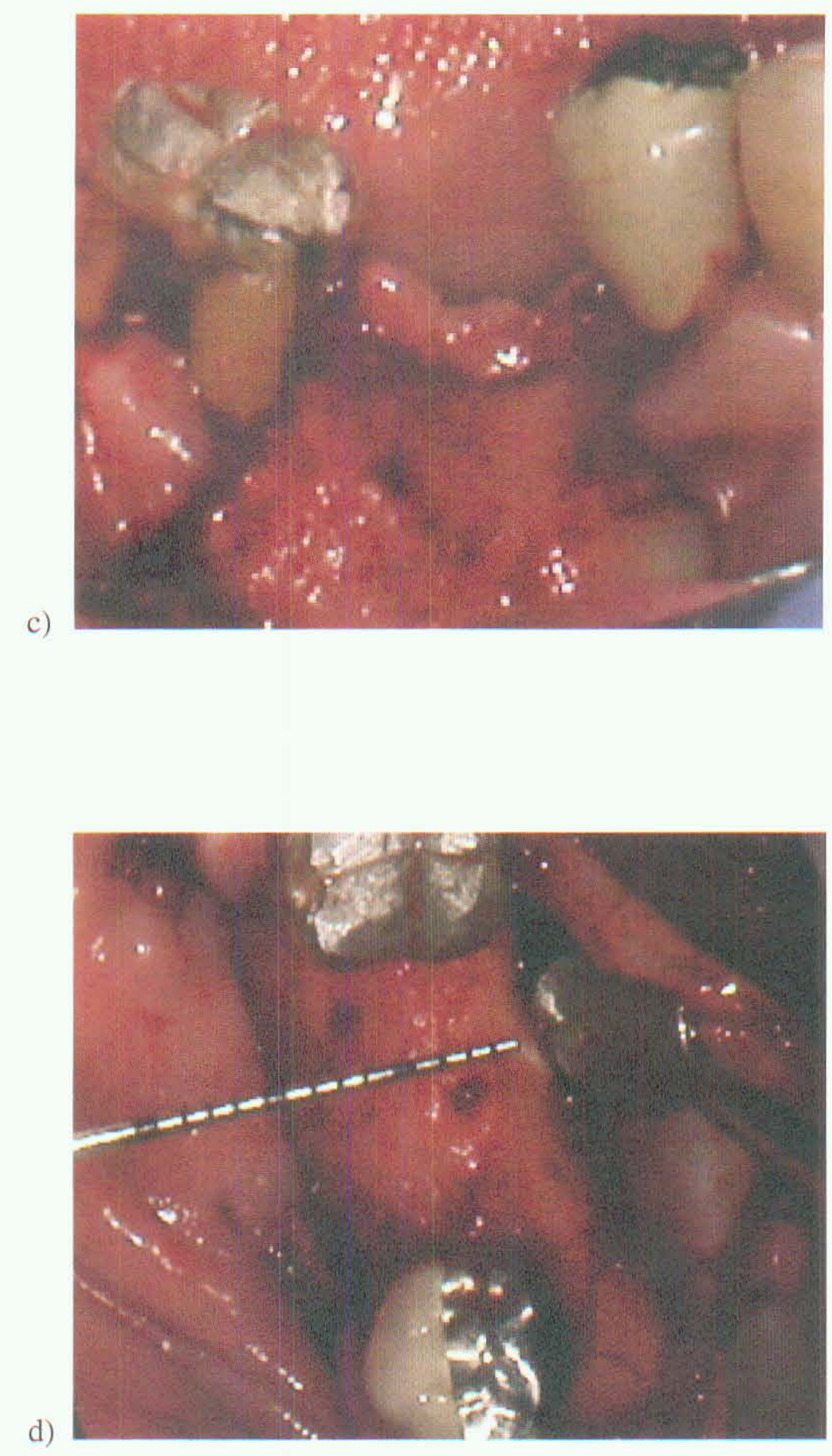

Figure 3. c) Particulate 4 month reentry facial; d) Paticulate 4 month reentry occlusal 


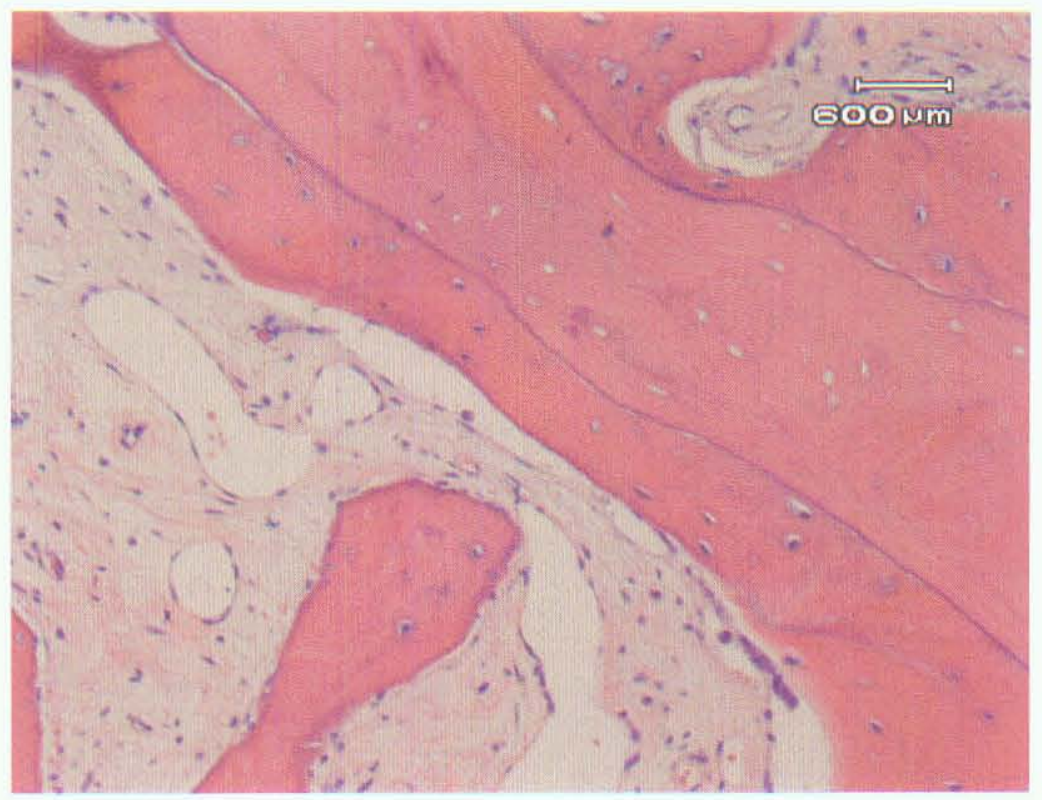

Figure 4. Vital Bone with Non- Vital Block Bone, 10X

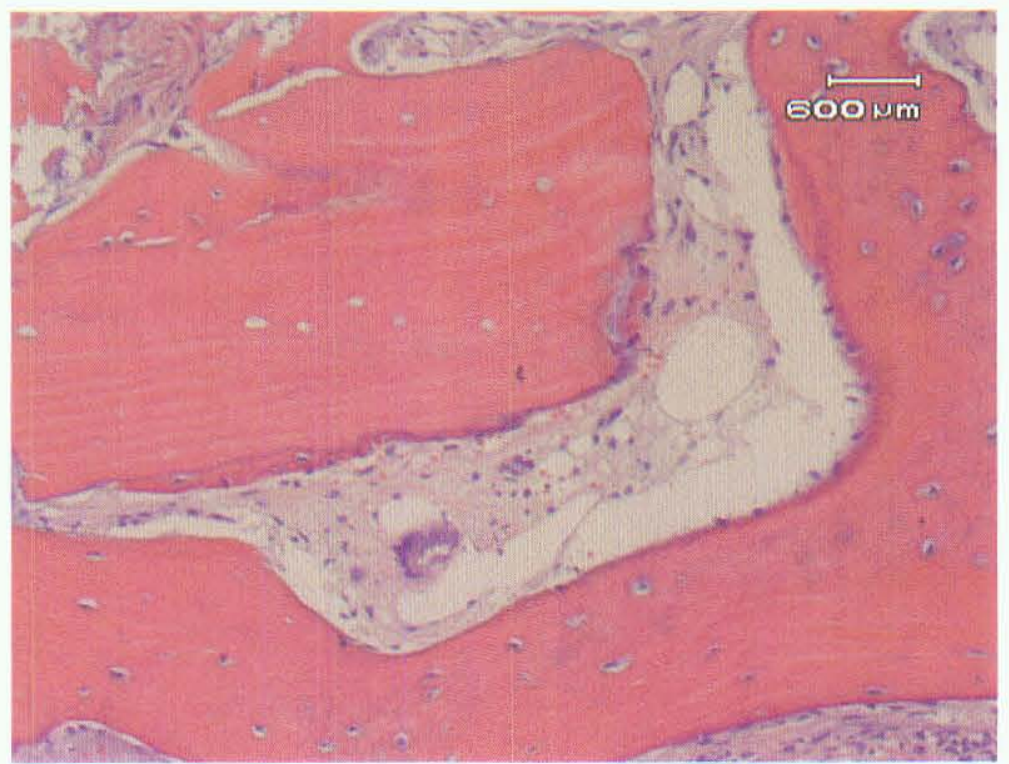

Figure 5. Non-Vital Paticulate Bone, and Vital Bone. 10X 


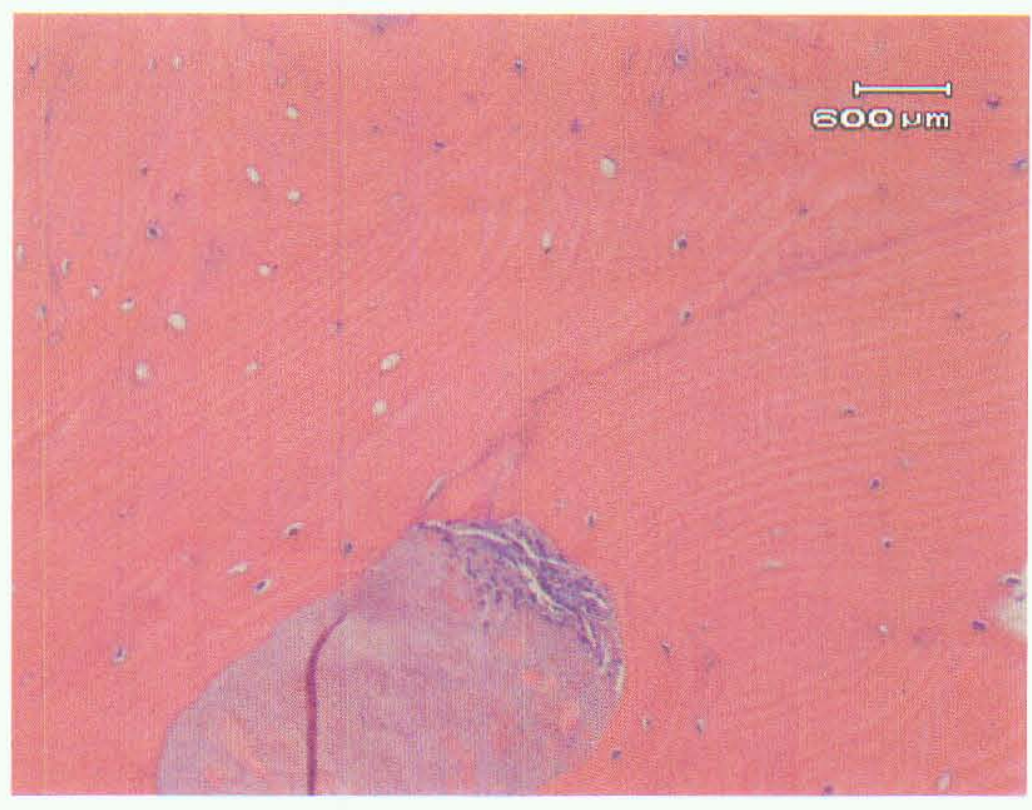

Figure 6. Mature Vital bone with amorphous organic matrix, 10X

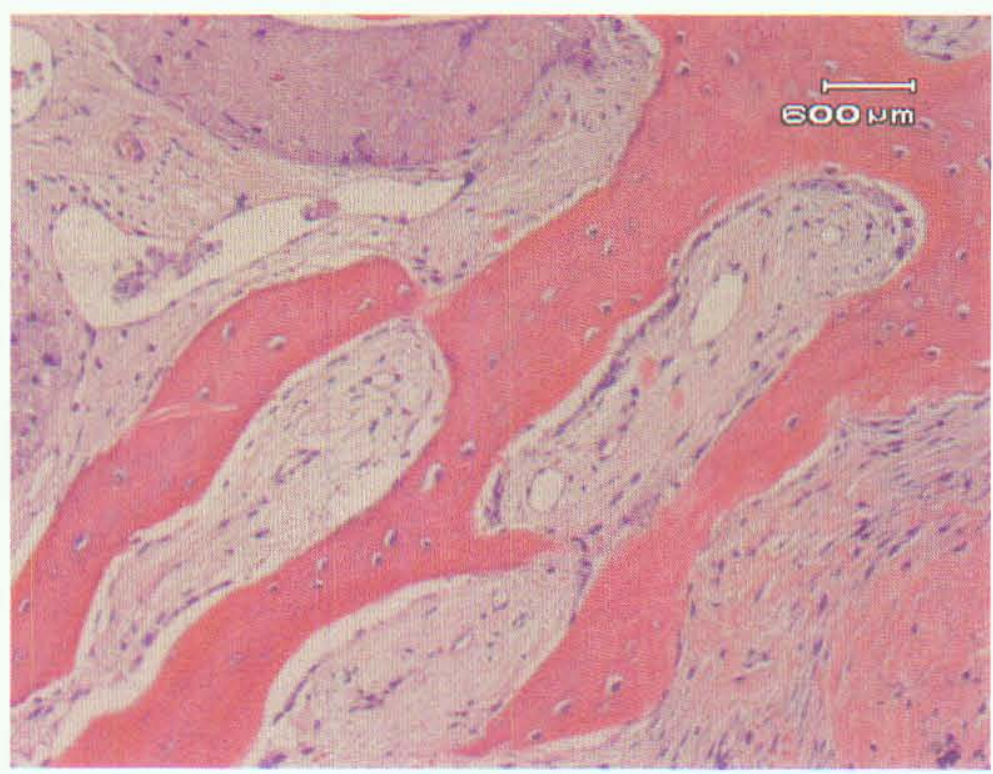

Figure 7. Vital bone and Vascular Channels, 10X 


\section{REFERENCES}

Albrektsson T, Zarb G, Worthington P, Eriksson AR. The long term efficacy of currently used dental implants: A review and proposed criteria of success Int J Oral Maxillofac Implants 1986;1(1):11-25.

Assenza B, Piattelli M, Scarano A, Iezzi G, Petrone G, Piattelli A. Localized ridge augmentation using titanium micromesh. J Oral Implantol 2001;27(6)287-292.

Bahat O, Koplin LM. Pantographic lip expansion and bone grafting for ridge augmentation. Int J Periodontics Restorative Dent 1989;9(5):345-353.

Batista EL, Batista FC. Managing soft tissue fenestrations in bone grafting surgery with an acellular dermal matrix: a case report. Int J Oral Maxillofac Implants 2001;16(6):875879.

Becker W, Becker BE, McGuire MK. Localized ridge augmentation using absorbable pins and e-PTFE barrier membranes: a new surgical technique. Case reports. Int $\mathbf{J}$ Periodontics Restorative Dent 1994;14(1):49-61.

Burchardt H. The biology of bone graft repair. Clin Orthop 1983;174:00:0028-42.

Buser D, Bragger U, Lang NP, Nyman S. Regeneration and enlargement of jaw bone using guided tissue regeneration. Clin Oral Implants Res 1990;1(1):22-32.

Buser D, Dula K, Belser UC, Hirt HP, Berthold H. Localized ridge augmentation using guided bone regeneration. I. Surgical procedure in the maxilla. Int J Periodontics Restorative Dent 1993;13(1):29-45.

Buser D, Dula K, Belser UC, Hirt HP, Berthold H. Localized ridge augmentation using guided bone regeneration. II. Surgical procedure in the mandible. Int J Periodontics Restorative Dent 1995;15(1):11-29.

Buser D, Hoffmann B, Bernard JP, Lussi A, Mettler D, Schenk RK. Evaluation of filling materials in membrane-protected bone defects: a comparative histomorphometric study in the mandible of miniature pigs. Clin Oral Implants Res 1998;9(3):137-150. 
Chiapasco M, Abati S, Romeo E, Vogel G. Clinical outcome of autogenous bone blocks or guided bone regeneration with e-PTFE membranes for the reconstruction of narrow edentulous ridges. Clin Oral Implants Res 1999;10(4):278-288.

Chiapasco M, Romeo E, Casentini P, Rimondini L. Alveolar distraction osteogenesis vs. vertical guided bone regeneration for the correction of vertically deficient edentulous ridges: a 1-3 year prospective study on humans. Clin Oral Implants Res 2004;15(1):8295.

Cordini F Ridge augmentation comparing a cancellous block allograft to demineralized bone matrix utilizing an acellular dermal matrix barrier membrane. Thesis. University of Louisville, 2004.

Dahlin C, Gottlow J, Linde A, Nyman S. Healing of maxillary and mandibular bone defects using a membrane technique: an experimental study in monkeys. Scand j Plast Reconst Hand Surg 1990;24(1):13-19.

Dahlin C, Linde A, Gottlow J, Nyman S. Healing of bone defects by guided tissue regeneration. Plast Reconstr Surg 1988;81(5):672-676.

de Carvalho PS, Vasconcellos LW, Pi J. Influence of bed preparation on the incorporation of autogenous bone grafts: a study in dogs. Int J Oral Maxillofac Implants 2000; 15(4):565-570.

Eppley BL. Experimental assessment of the revascularization of acellular human dermis for soft-tissue augmentation. Plast Reconstr Surg 2001;107(3):757-762.

Feuille F, Knapp CI, Brunsvold MA, Mellonig JT. Clinical and histologic evaluation of bone replacement grafts in the treatment of localized alveolar ridge defects. Part 1. Mineralized freeze-dried bone allograft. Int $J$ Periodontics Restorative Dent $2003 ; 23(1): 29-35$.

Fowler EB, Breault LG, Rebitski G. Ridge preservation utilizing an acellular dermal allograft and demineralized freeze-dried bone allograft:part II. Immediate endosseous implant placement. J Periodontol 2000;71(8):1360-1364.

Fowler EB, Breault LG, Rebitski G. Ridge preservation utilizing an acellular dermal allograft and demineralized freeze-dried bone allograft:part I. A report of 2 cases. J Periodontol 2000;71(8):1353-1359.

Friedmann A, Strietzel FP, Maretzki B, Pitaru S, Bernimoulin JP. Histological assessment of augmented jaw bone utilizing a new collagen barrier membrane compared to a standard barrier membrane to protect a granular bone substitute material : a randomized clinical trial. Clin Oral Implants Res 2002;13(6):587-594. 
Fritz ME, JeffcoatMK, Reddy M, Koth D, Braswell LD, Malmquist, Lemons J. Implants in regenerated bone in a primate model. J Periodontol 2001;72(6):703-708.

Fugazzotto PA. Success and failure rates of osseointegrated implants in function in regenerated bone for 6 to 51 months: a preliminary report. Int J Oral Maxillofac Implants 1997;12(1):17-24.

Fugazzotto PA. Report of 302 consecutive ridge augmentation procedures: technical considerations and clinical results. Int J Oral Maxillofac Implants 1998;13(3):358-368.

Fugazzotto PA, DePaoli S. Maintenance of regenerated bone beneath pontics: preliminary clinical report of 43 sites. Int J Oral Maxillofac Implants 1999;14(3):392397.

Goldberg VM, Stevenson S. Natural history of autografts and allografts. Clin Orthop 1987;225:7-16.

Gottlow J, Nyman S, Karring T, Lindhe J. New attachment formation as the result of controlled tissue regeneration. J Clin Periodontol 1984;11(8):494-503.

Greenwell H, Vance G, Munninger B, Johnston H. The superficial layer split thickness flap for maximal coronal positioning and flap release: A surgical technique. Int J Periodontics Restorative Dent 2004; In press.

Griffin TJ, Cheung WS, Hirayama H. Hard and soft tissue augmentation in implant therapy using acellular dermal matrix. Int $J$ Periodontics Restorative Dent 2004;24(4):351-362.

Haney JM, Nilveus RE, McMillan PJ, Wikesjo UM. Periodontal repair in dogs: expanded polytetrafluoroethylene barrier membranes support wound stabilization and enhance bone regeneration. J Periodontol 1993;64(9):883-890.

Harris RJ. Root coverage with a connective tissue with a partial thickness double pedicle graft and an acellular dermal matrix graft: a clinical and histological evaluation of a case report. J Periodontol 1998;5(4):1305-1311.

Henderson RD, Greenwell H, Drisko C, Regennitter FJ, Lamb JW, Mehlbauer MJ, Goldsmith LJ, Rebitski G. Predictable multiple site root coverage using an acellular dermal matrix allograft. J Periodontol 2001;72(5):571-582.

Hurley LA, Stinchfield FE, Bassett CA, Lyon WL. The role of soft tissues in osteogenesis. J Bone Joint Surg Am 1959;41a:1243-1254.

Johnston H. Comparison of Gore-Tex and Alloderm membranes for guided tissue regeneration of class II furcation defects treated with Grafton demineralized bone matrix putty. Thesis. University of Louisville. 2003. 
Jovanovic SA, Nevins M. Bone formation utilizing titanium-reinforced barrier membranes. Int J Periodontics Restorative Dent 1995;15(1):57-69.

Kaufman E, Wang PD. Localized vertical maxillary ridge augmentation using symphyseal bone cores: a technique and case report. Int J Oral Maxillofac Implants 2003;18(2):293-298.

Keith JD. Localized ridge augmentation with a block allograft followed by secondary implant placement: a case report. Int J Periodontics Restorative Dent 2004;24(1):11-17.

Knapp CI, Feuille F, Cochran DL, Mellonig JT. Clinical and histologic evaluation of bone replacement grafts in the treatment of localized alveolar ridge defects. Part 2. Bioactive glass particulate. Int J Periodontics Restorative Dent 2003;23(3):129-138.

Lekholm U, Zarb G. Patient selection and prearation. In Branemark P-I, Zarb GA, Albrektsson T, editors: Tissue integrated prosthesis: osseointegration in clinical dentistry. Quintessence Int 1985;199-209.

Leonetti JA, Koup R. Localized maxillary ridge augmentation with a block allograft for dental implant placement: case reports. Implant Dent 2003;12(3):217-226.

Lin KY, Bartlett SP, Yaremchuk MJ, Fallon M, Grossman R, Whitaker LA. The effect of rigid fixation on the survival of onlay bone grafts: an experimental study. Plast Reconstr Surg 1990;86(3):449-456.

Loe $\mathrm{H}$. The gingival index, the plaque index, and retention index systems. J Periodontol 1967;38(Suppl):610-617.

Lyford RH, Mills MP, Knapp CI, Scheyer ET, Mellonig JT. Clinical evaluation of freezedried block allografts for alveolar ridge augmentation : a case series. Int J Periodontics Restorative Dent 2003;23(5):417-425.

Machtei EE. The effect of membrane exposure on the outcome of regenerative procedures in humans: a meta-analysis. J Periodontol 2001;72(4):512-516.

Majzoub Z, Berengo M, Giardino R, Aldini N, Cordioli G. Role of intramarrow penetration in osseous repair:a pilot study in the rabbit calvaria. J Periodontol 1999;70(12):1501-1510.

Mattout P, Mattout C. Conditions for success in guided bone regeneration: retrospective study on 376 implant sites. J Periodontol 2000;71(12):1904-1909.

Misch C. Contemporary Implant Dentistry, ed 2. St. Louis: Mosby, 1999:1 
Nevins M, Mellonig JT. Enhancement of the damaged edentulous ridge to receive dental implants: a combination of allograft and the Gore-Tex membrane. Int J Periodontics Restorative Dent 1992;12(2):97-111.

Nevins M, Mellonig JT. The advantages of localized ridge augmentation prior to implant placement: a staged event. Int J Periodontics Restorative Dent 1994;14(2):97-111.

Nevins M, Mellonig JT, Clem DS, Reiser GM, Buser DA. Implants in regenerated bone: Lomg term survival. Int J Periodontics Restorative Dent 1998;18(1):35-45.

Novaes AB, Souza SL. Acellular dermal matrix graft as a membrane for guided bone regeneration: a case report. Implant Dent 2001;10(3):192-196.

Nyman S, Lang NP, Buser D, Bragger U. Bone regeneration adjacent to titanium dental implants using guided tissue regeneration: a report of two cases. Int $\mathbf{J}$ Oral Maxillofac Implants 1990;5(1):9-14.

Ozaki W, Buchman SR. Volume maintenance of onlay bone grafts in the craniofacial skeleton: microarchitecture versus embryologic origin. Plast Reconstr Surg 1998;102(2):291-299.

Roos J, Sennerby L, Lekholm U, Jemt T, Grondahl K, Albrektsson T. A qualitative and quantitative method for evaluating implant success: A 5-year retrospective analysis of the Branemark implant. Int J Oral Maxillofac Implants 1997;12(4):504-514.

Sandberg E, Dahlin C, Linde A. Bone regeneration by the osteopromotion technique using bioabsorbable membranes: an experimental study in rats. J Oral Maxillofac Surg 1993;51(10):1106-1114.

Seibert JS. Treatment of moderate localized alveolar ridge defects. Dent Clin North Am 1993;37(2):265-280.

Shanaman RH. The use of guided tissue regeneration to facilitate ideal prosthetic placement of implants. Int J Periodontics Restorative Dent 1992;12(4):256-265

Silness J, Loe H. Periodontal disease in pregnancy. Acta Odontol Scand 1964:22:121135.

Simion M, Baldoni M, Rossi P, Zaffe D. A comparative study of the effectiveness of ePTFE membranes with and without early exposure during the healing period. Int $\mathbf{J}$ Periodontics Restorative Dent 1994;14(2):167-180.

Simion M, Baldoni M, Zaffe D. Jawbone enlargement using immediate implant placement associated with a split-crest technique and guided tissue regeneration. Int $\mathbf{J}$ Periodontics Restorative Dent 1992;12(6):463-473. 
Smith JD, Abramson M. Membranous vs. endochondral bone autografts. Arch Otolaryng 1974;99(3):203-205.

Tagge DL, O'Leary TJ, El-Kafrawy AH. The clinical and histologic response of periodontal pockets to root planing and oral hygiene. J Periodontol 1975;46(9):527-533.

Urist MR. Practical applications of basic research on bone graft physiology. A.A.O.S.: Instructional course lectures 1976;1-26

Urist MR, Silverman BF, Buring K, Dubuc FL, Rosenberg JM. The bone induction principle. Clin Orthop 1967;53:243-283.

Wainwright D, Madden M, Luterman A, Hunt J, Monafo W, Heimbach D, Kagan R, Sittig K, Dimick A, Herndon D. Clinical evaluation of an acellular allograft dermal matrix in full-thickness burns. J Burn Care Rehabil 1996;17(2):124-136.

Wallace SS, Froum SJ. Effect of maxillary sinus augmentation on the survival of endosseous dental implants. A systematic review. Ann Periodontol 2003;8(1):328-343.

Wang H, Misch C, Neiva RF. "Sandwich" bone augmentation technique: rationale and report of pilot cases. Int J Periodontics Restorative Dent 2004;24(3):232-245.

Wikesjo UM, Nilveus R. Periodontal repair in dogs: effect of wound stabilization on healing. J Periodontol 1990;61(12):719-724.

Zins JE, Whitaker LA. Membranous versus endochondral bone: implications for craniofacial reconstruction. Plast Reconstr Surg 1983;72(6):778-785.

Zitzmann NU, Naef R, Scharer P. Resorbable versus non-resorbable membranes in combination with Bio-Oss for guided bone regeneration. Int $\mathrm{J}$ Oral Maxillofac Implants $1997 ; 12(6): 844-852$. 


\section{Appendix A}

\section{The Plaque Index}

The plaque index of Silness and Loe (1964) will be measured. Scores will be as follow:

0 - No plaque

1 - A film of plaque adhering to the free gingival margin and adjacent area of the tooth. The plaque may be seen in situ only after application of disclosing solution or by using the probe on the tooth surface.

2 - Moderate accumulation of soft deposits within the gingival pocket, or on the tooth and gingival margin, which can be seen with the naked eye.

3 - Abundance of soft matter within the gingival pocket and/or on the tooth and gingival margin.

Each gingival unit (buccal, lingual, mesiobuccal, distobuccal, mesiolingual, and distolingual) of the individual tooth was given a score from $0-3$, called the plaque index for the area. The scores from the 6 areas of the tooth were added and divided by 6 to give the plaque index for the tooth. 


\section{Appendix B}

\section{Gingival Index}

The gingival index of Loe (1967) will be measured for the test and control sites. Scores will be recorded as follows:

$0=$ Normal gingiva

$1=$ Mild inflammation - slight change in color slight edema, no bleeding on probing.

$2=$ Moderate inflammation - redness, edema, and glazing, bleeding on probing.

$3=$ Severe inflammation - marked redness and edema, ulceration and tendency to spontaneous bleeding.

Each gingival unit (mesiobuccal, buccal, distobuccal, distolingual, lingual, mesiolingual) of the tooth will be given a score $0-3$. The scores for each unit will be added together and divided by 6 to give the gingival index for that tooth. The score of the test tooth and the two adjacent teeth will be added and divided by 3 to give the gingival index for the test of control sites. 


\section{Appendix C}

\section{Tooth Mobility (Laster et al. 1975)}

A modification of Miller's index was used to measure tooth mobility as suggested by Laster et al. 1975. Miller suggested the following scoring system:

$0=$ Movability of the crown within normal physiologic limits.

$1=$ Movability of the crown up to $0.5 \mathrm{~mm}$ in one direction. Does not exceed $1.0 \mathrm{~mm}$ in both directions.

$2=$ Movability of the crown from 0.5 to $1 \mathrm{~mm}$ in one direction. Does not exceed 2.0 $\mathrm{mm}$ in both directions..

$3=$ Movability of the crown exceeding $1 \mathrm{~mm}$ in one direction and/or vertical depressibility. Greater than $2.0 \mathrm{~mm}$ in both directions and/or vertical depressibility.

The index that was used in the study is a modification of Miller's index (Laster et al. 1975) where half scores could be used. Thus scores of $0,0.5,1,1.5,2,2.5$, and 3 were utilized. 


\section{Appendix D}

\section{Standardized Radiographic technique}

An occlusal stent was used to provide a stable foundation for the radiograph holder. A light cured resin material was placed on a Rinn radiograph holder and positioned to allow as near as possible paralleling technique. This material was light

cured so that standardized radiographs can be compared. Radiographs were taken at baseline and 4 months. 


\section{Appendix E}

\section{Arithmetic determinations:}

Ridge width $($ Post-extraction $)=$ A digital caliper was used to measure total ridge width to the nearest $10^{-2} \mathrm{~mm}$ at one point, mid socket, at the alveolar crest and $5 \mathrm{~mm}$ from the alveolar crest.

Ridge width $(4$ month re-entry $)=$ Again, a digital caliper measured total ridge width to the nearest $10^{-2} \mathrm{~mm}$ at one point, mid socket, at the alveolar crest and $5 \mathrm{~mm}$ from the alveolar crest.

Change in alveolar crest $\mathbf{-}$ direct $=$ Initial: stent to alveolar crest minus re-entry stent to alveolar crest.

Alveolar Crest Width $=$ Crestal width was measured with digital calipers during the initial surgical appointment and evaluated to determine if a relationship exists between ridge width and height and the thickness of the crestal bone.

Tissue thickness $=[$ Initial: $\mathrm{SDM}$ gingival thickness meter $3 \mathrm{~mm}$ apical to the soft tissue crest on buccal and palato/lingual] - [4 month SDM gingival thickness meter 3 $\mathrm{mm}$ apical to the soft tissue crest on buccal and palato/lingual with the addition of one measurement at the center of the occlusal aspect of the ridge]. 


\section{Appendix F}

\section{$\underline{\text { Stent fabrication }}$}

Rigid stents were made of $3 \mathrm{~mm}$ thick light cured resin material in order to provide reproducible measurements. The tooth to be extracted was ground off the model and the light cured resin material was pressed over a cast. Three channels were prepared on the labial and three on the palato/lingual aspect of the stent in which a North Carolina periodontal probe was placed so that mesial, mid and distal measurements could be made on the labial and palato/lingual aspects of the crestal bone. Additionally, two channels were also prepared on the occlusal portion of the stent to provide measures of mesial and distal occlusal ridge height. Holes were prepared with a high-speed hand-piece. In this way, reproducible probing spots and directions of probe insertions were possible. 


\section{Appendix G}

\section{Histologic Analysis}

Ten serial sections from each study subject were stained and made available for histologic analysis. Three slides and two fields per slide (6 fields in total) will be randomly selected from to evaluate the percent vital bone, percent non-vital bone, percent trabecular space, and number of osteoblasts using a reticle (with a $10 \times 10$ boxed field) at a power of $150 \mathrm{X}$. A box is to be counted as containing a specific histologic tissue if it was filled $90 \%$ or more by the respective tissue. The mean percentages of the various histologic components will be tabulated and reported as mean percentages. 


\section{Appendix H}

\section{Soft Tissue Thickness Measurements}

Soft tissue measurements were taken at three positions. The first was on the buccal $3 \mathrm{~mm}$ apical to the soft tissue crest. The second was on the occlusal mid crestally. The third was on the lingual $3 \mathrm{~mm}$ apical to the soft tissue crest. The measurements were taken at initial and reentry appointments. 


\title{
CURRICULUM VITAE
}

\author{
Brenton Lahey, DMD, MS
}

\section{EDUCATION}

2002-2005 University of Louisville Graduate Periodontics Certificate in Periodontics

2002-2005 University of Louisville Master of Science in Oral Biology

1998-2002 Temple University School of Dentistry Doctor of Dental Medicine (D.M.D)

1994-1998 Wesleyan University

Bachelor of Arts (B.A.)

\section{LICENSURE}

June 2002-Present Commonweatlh of Kentucky Dental License June 2002-Present State of Florida Dental License

Category II Laser certification 2002

DEA licensure granted 2002

CPR certification 2004

ACLS certification 2005 


\section{PROFESSIONAL ASSOCIATIONS}

American Dental Association member

Kentucky Dental Association member

American Academy of Periodontology member

Academy of Osseointegration member

\section{RESEARCH ACTIVITIES}

Lahey B, Greenwell H, Hill M, Adams D, Sheetz J. Ridge Augmentation Comparing a Cancellous Block Allograft to Freeze Dried Bone Particles Utilizing an Acellular Dermal Matrix as a Barrier Membrane. Submitted for publication.

\section{EXTERNSHIPS}

Internal Medicine Rotation, University of Louisville Hospital June 2004 Anesthesiology Rotation, University of Louisville Hospital May 2004 